\title{
HEDELMÄNVILJELYÄ KOHDANNEESTA TUHOSTA v. 1955-56
}

\author{
JАAKKо SÄKÖ \\ Puntarhantutkimuslaitos, Piikkiö
}

Saapunut 17. 1. 1957

Maamme hedelmänviljelylle aiheutui jälleen varsin tuntuvaa vahinkoa talven 1955 - 56 oltua poikkeuksellisen ankara. Tällä kertaa tuhot eivät olleet kaikkialla maassamme läheskään yhtä suuria kuin vuosina 1939—42. Mm. Lounais- ja EteläSuomessa osoittautui tuhojen laajuus varsin vaihtelevaksi. Näillä alueilla on hedelmätarhoja, joissa vaurioita ei ole esiintynyt juuri nimeksikään, kun taas toisissa on huomattava osa puista tuhoutunut. Paljon ankarampaa vahinkoa kuin mainituilla alueilla talvi sai aikaan sisämaassa. Niinpä Keski-Suomesta, Savosta ja Pohjois-Karjalasta on ilmoitettu monien hedelmätarhojen kärsineen suorastaan täydellisen tuhon.

Hedelmäpuiden talvehtimista pyrittiin tunnustelemaan jo kevättalvella tarkastamalla silmujen avautumista vedessä pidetyissä versoissa. Koska versojen lehdittyminen osoittautui hyväksi eri lajikkeilla, luultiin puiden selviytyneen varsin hyvin yli talven. Puiden leikkausaikana, huhtikuussa, voitiin vauriota kuitenkin jo havaita. Tässä vaiheessa todettiin erityisesti lumen rajassa olleiden oksien vaurioituneen. Vasta kesän kuluessa alkoi tuhojen laajuus ja laatu käydä esiin. Monet puut, jotka leikkausaikana näyttivät terveiltä, menehtyivät myöhemmin kesällä.

Tuhojen selville saamiseksi suoritti Puutarhantutkimuslaitos yhteistyössä Hedelmänviljelijäin yhdistyksen kanssa tiedustelun hedelmäpuiden talvehtimisesta eri puolilla maata. Viljelijöille toimitetuissa tiedustelulomakkeissa pyydettiin tietoja eri hedelmäpuulajien ja -lajikkeiden terveinä säilyneiden, vaurioituneiden ja kuolleiden puiden määrästä sekä vaurioitumisen laadusta. Edelleen pyydettiin siinä mainitsemaan millä perusrungolla puut kasvavat, sekä ilmoittamaan tiedot maanlaadusta, ojituksesta, maastosuhteista, maanpinnan hoitotavasta ja tuulensuojasta. Vielä pyydettiin tietoja v:n 1955 lannoituksesta, kastelusta ja leikkauksesta. Lomakkeita lähetettiin kaikkiaan $717 \mathrm{kpl}$. Niistä palautettiin 195, joista 171 eli $24 \%$ lähetetyistä oli täytetty ohjeiden mukaan.

Seuraavassa selvitetään mainitusta aineistosta saatuja tuloksia alueittain. Sitä ennen luodaan katsaus kasvukauden 1955 ja talven 1955 - 56 sääoloihin. 
Kasvukausi 1955 oli kesä-, heinä- ja elokuun osalta koko maassa erittäin kuiva (taulukko 1). Mainittujen kuukausien sademäärät jäivät kaikkialla normaalia huomattavasti alhaisemmiksi. Mm. Ahvenanmaan, Turun ja Porin sekä Uudenmaan läänissä saatiin sadetta vain neljäsosa tavallisesta määrästä. Yksinäisissä havaintopaikoissa saattoivat sademäärät jäädä hyvinkin alhaisiksi. Niinpä Puutarhantutkimuslaitoksella satoi heinäkuussa vain 9.4 ja elokuussa $4.6 \mathrm{~mm}$. Mainittujen kuukausien normaaliarvot ovat tällä havaintopaikalla 67 ja $76 \mathrm{~mm}$.

Syys- ja lokakuu sitä vastoin olivat tavallista sateisempia. Lisäksi nämä kuukaudet olivat suurimmassa osassa maata normaalia lämpimämpiä (taulukko 2).

Marraskuun lopulla tapahtui sääsuhteissa nopea muutos. Maamme yli kulki voimakas pakkasaalto, jolloin $\mathrm{mm}$. Keski-Suomessa lämpötila laski $-27^{\circ}$ :seen. Niinikään joulukuu oli huomattavasti normaalia kylmempi. Sen aikana esiintyi eri puolilla maata 2-3 viikkoa kestänyt pakkaskausi, jolloin Etelä-Suomessakin mitattiin $-30^{\circ}$ :n pakkasia. Joulukuun lopulla sää kuitenkin lauhtui koko maassa. Tällöin mm. Lounais-Suomessa hävisi marras- ja joulukuun aikana satanut lumi miltei kokonaan.

Tammi- ja helmikuussa oli useita päiviä kestäneitä ankaria pakkasia. Etenkin helmikuu oli huomattavasti normaalia kylmempi. Sen aikana ei koko maassa Ahvenanmaata lukuunottamatta esiintynyt kertaakaan suojasäätä (Ilmatieteellisen Keskuslaitoksen kuukausikatsaukset 6-12 1955 ja 1-4 1956).

Paksun lumipeitteen takia maa ei routaantunut kovinkaan syvälle. Piikkiössä, Puutarhantutkimuslaitoksen hedelmätarhassa, routakerroksen vahvuus oli keskitalvella $32 \mathrm{~cm}$ mulloksessa ja $24 \mathrm{~cm}$ nurmessa. Toukokuun alussa todettiin roudan jo kokonaan hävinneen.

Taulukko 1. Sademäärä ja sen normaaliarvot lääneittäin kesäkuusta lokakuuhun 1955.

Table 1. Monthly vainfall from June to October 1955, according to province, and its normal values.

\begin{tabular}{|c|c|c|c|c|c|c|c|c|c|c|}
\hline \multirow[b]{2}{*}{$\begin{array}{l}\text { Lääni } \\
\text { Province }\end{array}$} & \multicolumn{2}{|c|}{$\begin{array}{c}\text { Kesãkuu } \\
\qquad J u n i\end{array}$} & \multicolumn{2}{|c|}{$\begin{array}{l}\text { Heinãkuu } \\
\qquad J u l i\end{array}$} & \multicolumn{2}{|c|}{$\begin{array}{l}\text { Elokuu } \\
\text { August }\end{array}$} & \multicolumn{2}{|c|}{$\begin{array}{l}\text { Syyskuu } \\
\text { September }\end{array}$} & \multicolumn{2}{|c|}{$\begin{array}{c}\text { Lokakuu } \\
\text { October }\end{array}$} \\
\hline & $\begin{array}{l}1955 \\
\mathrm{~mm}\end{array}$ & $\begin{array}{l}\text { Norm. } \\
\text { Normal } \\
\text { mm }\end{array}$ & $\begin{array}{l}1955 \\
\mathrm{~mm}\end{array}$ & $\begin{array}{l}\text { Norm. } \\
\text { Normal } \\
\text { mm }\end{array}$ & $\begin{array}{l}1955 \\
\mathrm{~mm}\end{array}$ & $\begin{array}{l}\text { Norm. } \\
\text { Normal } \\
\mathrm{mm}\end{array}$ & $\begin{array}{l}1955 \\
\mathrm{~mm}\end{array}$ & $\begin{array}{c}\text { Norm } \\
\text { Normal } \\
\text { mm }\end{array}$ & $\begin{array}{l}1955 \\
\mathrm{~mm}\end{array}$ & $\begin{array}{c}\text { Norm. } \\
\text { Normal } \\
\mathrm{mm}\end{array}$ \\
\hline
\end{tabular}

\section{Ahvenanmaa sekä}

Turun ja Porin lääni 23

Uudenmaan lääni 41

Kymen lääni $\quad 28$

Hämeen läåni $\quad 28$

Mikkelin lääni 23

Vaasan lăåni

$\begin{array}{ll}46 & 16 \\ 51 & 17 \\ 60 & 38 \\ 57 & 32 \\ 62 & 26 \\ 57 & 42 \\ 64 & 29\end{array}$

$\begin{array}{ll}63 & 20 \\ 66 & 20 \\ 65 & 28 \\ 73 & 33 \\ 66 & 24 \\ 68 & 26 \\ 69 & 17\end{array}$

73
83
82
77
74
76
77

78
72
87
84
96
99
105

$\begin{array}{ccc}61 & 103 & 65 \\ 72 & 91 & 74 \\ 75 & 98 & 69 \\ 67 & 76 & 67 \\ 66 & 91 & 64 \\ 64 & 66 & 63 \\ 70 & 92 & 64\end{array}$


Taulukko 2. Kuukauden keskimääräiset, normaali- sekä minimilämpötilat syyskuusta huhtikuuhun.

Table 2. Monthly mean, normal, and minimum temperatures from September, 1955, to April, 1956.

\begin{tabular}{|c|c|c|c|c|c|c|c|c|c|c|c|c|}
\hline \multirow[t]{2}{*}{$\begin{array}{c}\text { Paikkakunta } \\
\text { Locality }\end{array}$} & $\begin{array}{l}\text { ด } \\
\stackrel{9}{=} \\
\circ\end{array}$ & 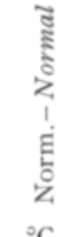 & $\begin{array}{c}\Xi \\
\vdots \\
\vdots \\
\dot{\Sigma}\end{array}$ & 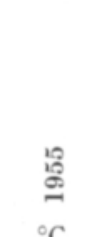 & 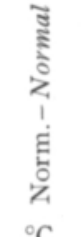 & $\underset{1}{\stackrel{\Xi}{\Xi}}$ & $\frac{10}{6}$ & 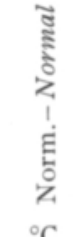 & 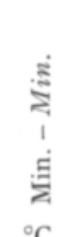 & $\begin{array}{l}\text { [0 } \\
\stackrel{2}{=}\end{array}$ & 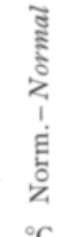 & $\underset{\vdots}{ \pm}$ \\
\hline & ${ }^{\circ} \mathrm{C}$ & ${ }^{\circ} \mathrm{C}$ & ${ }^{\circ} \mathrm{C}$ & ${ }^{\circ} \mathrm{C}$ & ${ }^{\circ} \mathrm{C}$ & ${ }^{\circ} \mathrm{C}$ & ${ }^{\circ} \mathrm{C}$ & ${ }^{\circ} \mathrm{C}$ & ${ }^{\circ} \mathrm{C}$ & ${ }^{\circ} \mathrm{C}$ & ${ }^{\circ} \mathrm{C}$ & ${ }^{\circ} \mathrm{C}$ \\
\hline & \multicolumn{3}{|c|}{$\begin{array}{l}\text { Syyskuu } \\
\text { September }\end{array}$} & \multicolumn{3}{|c|}{$\begin{array}{c}\text { Lokakuu } \\
\text { October }\end{array}$} & \multicolumn{3}{|c|}{$\begin{array}{l}\text { Marraskuu } \\
\text { November }\end{array}$} & \multicolumn{3}{|c|}{$\begin{array}{l}\text { Joulukuu } \\
\text { December }\end{array}$} \\
\hline Turku ......... & 13.2 & \multicolumn{2}{|l|}{10.3} & 5.4 & \multicolumn{2}{|l|}{5.1} & 0.0 & 0.4 & -17 & -8.0 & -3.3 & -25 \\
\hline Lohja $\quad \ldots \ldots \ldots \ldots$ & 13.6 & & & 6.2 & & & -0.2 & & -15 & -9.1 & & -29 \\
\hline Helsinki $\ldots \ldots \ldots \ldots$ & 14.8 & \multicolumn{2}{|l|}{10.8} & 7.2 & \multicolumn{2}{|l|}{5.5} & 0.2 & 0.6 & -17 & -8.6 & -3.3 & -29 \\
\hline Kotka $\quad \ldots \ldots \ldots$ & 13.9 & \multicolumn{2}{|l|}{10.6} & 6.6 & \multicolumn{2}{|l|}{5.0} & -1.5 & 0.2 & -21 & -12.4 & -4.3 & -30 \\
\hline Lepaa ........... & 13.0 & \multicolumn{2}{|l|}{10.0} & 4.9 & \multicolumn{2}{|l|}{4.1} & -2.0 & -0.2 & -22 & -12.0 & -4.0 & -32 \\
\hline Pälkäne ........ & 13.0 & \multicolumn{2}{|l|}{10.2} & 4.9 & \multicolumn{2}{|l|}{4.2} & -2.1 & -0.4 & -18 & -12.1 & -4.2 & -30 \\
\hline Lahti $\ldots \ldots \ldots \ldots$ & 12.6 & \multicolumn{2}{|l|}{9.4} & 4.8 & \multicolumn{2}{|l|}{3.7} & -2.7 & -0.6 & -22 & -13.0 & -4.6 & -32 \\
\hline Lappeenranta $\quad \ldots$. & 13.3 & \multicolumn{2}{|l|}{9.9} & 5.1 & \multicolumn{2}{|l|}{3.6} & -3.5 & -1.4 & -19 & -15.2 & -6.4 & -31 \\
\hline Mikkeli $\quad \ldots \ldots \ldots \ldots$ & 12.1 & \multicolumn{2}{|l|}{9.4} & 4.3 & \multicolumn{2}{|l|}{3.4} & -4.5 & -1.0 & -28 & -15.8 & -5.5 & -37 \\
\hline Jyvåskylä $\ldots \ldots \ldots$ & 11.3 & \multicolumn{2}{|l|}{8.8} & 3.2 & \multicolumn{2}{|l|}{3.2} & -5.2 & -1.9 & -27 & -15.6 & -6.3 & -35 \\
\hline Vaasa $\ldots \ldots \ldots \ldots$ & 12.0 & \multicolumn{2}{|l|}{9.3} & 4.0 & \multicolumn{2}{|l|}{4.0} & -1.8 & -0.8 & -18 & -11.2 & -4.5 & -30 \\
\hline Kuopio $\ldots \ldots \ldots$ & 11.9 & \multicolumn{2}{|l|}{9.1} & 3.7 & \multicolumn{2}{|l|}{3.2} & -5.0 & -2.2 & -24 & -17.3 & -7.1 & -37 \\
\hline & 点 & \multicolumn{2}{|l|}{ 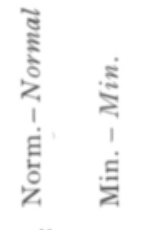 } & 兽 & 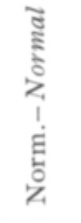 & $\underset{\vdots}{\Xi}$ & 兽 & 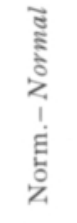 & 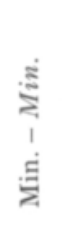 & ถึ & 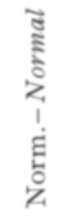 & $\underset{\vdots}{\Xi}$ \\
\hline & $\begin{array}{r}\text { Ta: } \\
J\end{array}$ & $\begin{array}{l}\text { mmikt } \\
\text { anuary }\end{array}$ & & $\begin{array}{l}\mathrm{Hel} \\
\mathrm{Fel}\end{array}$ & $\begin{array}{l}\text { Imikuu } \\
\text { bruary }\end{array}$ & & & $\begin{array}{l}\text { aliskt } \\
\text { March }\end{array}$ & & & $\begin{array}{l}\text { uhtiku } \\
\text { April }\end{array}$ & \\
\hline Turku .......... & -7.9 & -4.8 & -31 & -12.4 & -5.5 & -32 & -3.1 & -2.5 & -20 & 0.6 & 2.6 & -13 \\
\hline Lohja .......... & -7.9 & & -30 & -13.4 & & -34 & -3.6 & & -25 & 0.2 & & -18 \\
\hline Helsinki $\ldots \ldots \ldots \ldots$ & -6.2 & -5.3 & -27 & -12.0 & -5.6 & -28 & -3.1 & -2.6 & -14 & 0.9 & 2.4 & -12 \\
\hline Kotka .......... & -8.4 & -6.5 & -32 & -14.3 & -7.0 & -32 & -6.2 & -3.5 & -21 & -0.6 & 1.8 & -21 \\
\hline Lepaa....$\ldots \ldots$ & -9.6 & -7.4 & -35 & -14.2 & -7.8 & -36 & -3.9 & -3.8 & -26 & 0.0 & 2.4 & -16 \\
\hline Pälkäne $\ldots . . \ldots$. & -9.8 & -7.6 & -31 & -14.2 & -7.8 & -33 & -3.7 & -3.7 & -22 & -0.3 & 2.0 & -13 \\
\hline Lahti $\ldots . . . . .$. & -9.7 & -7.8 & -31 & -14.1 & -8.2 & -32 & -3.8 & -4.2 & -24 & -0.4 & 2.0 & -16 \\
\hline Lappeenranta $\ldots$. & -10.6 & -8.2 & -31 & -14.8 & -8.4 & -34 & -4.0 & -3.7 & -17 & -0.1 & 2.4 & -16 \\
\hline Mikkeli $\ldots \ldots \ldots$ & -11.5 & -8.8 & -36 & -16.0 & -9.0 & -39 & -6.2 & -4.6 & -30 & -1.2 & 1.9 & -24 \\
\hline Jyväskylä $\ldots \ldots \ldots$ & -11.8 & -8.1 & -36 & -15.6 & -8.5 & -38 & -5.3 & -4.4 & -27 & -1.6 & 1.5 & -18 \\
\hline Vaasa $\ldots \ldots \ldots \ldots$ & -9.7 & -5.8 & -32 & -12.4 & -6.6 & -33 & -3.4 & -3.8 & -19 & -1.1 & 0.8 & -19 \\
\hline Kuopio $\ldots \ldots \ldots$ & -11.5 & -9.0 & -32 & -15.6 & -9.6 & -36 & -4.8 & -5.0 & -24 & -1.2 & 1.0 & -19 \\
\hline
\end{tabular}




\section{Aineiston käsittely}

Ryhdyttäessä käsittelemään hedelmäpuiden talvehtimistiedustelusta kertynyttä aineistoa tuntui luonnollisimmalta jaotella se eri hedelmänviljelyvyöhykkeiden mukaan. Sangen pian tarkastelu kuitenkin osoitti, että saman vyöhykkeen eri osissa ilmeni puiden talvehtimisessa selviä eroavuuksia. Tämän vuoksi vastaukset ryhmiteltiin alueittain hedelmänviljelyvyöhykkeitä osittamalla. Nämä alueet, jotka käyvät tarkemmin selville oheisesta kartasta (kuva 1), sekä niitä koskevat vastaukset ja alueiden puumäärät ovat seuraavat:

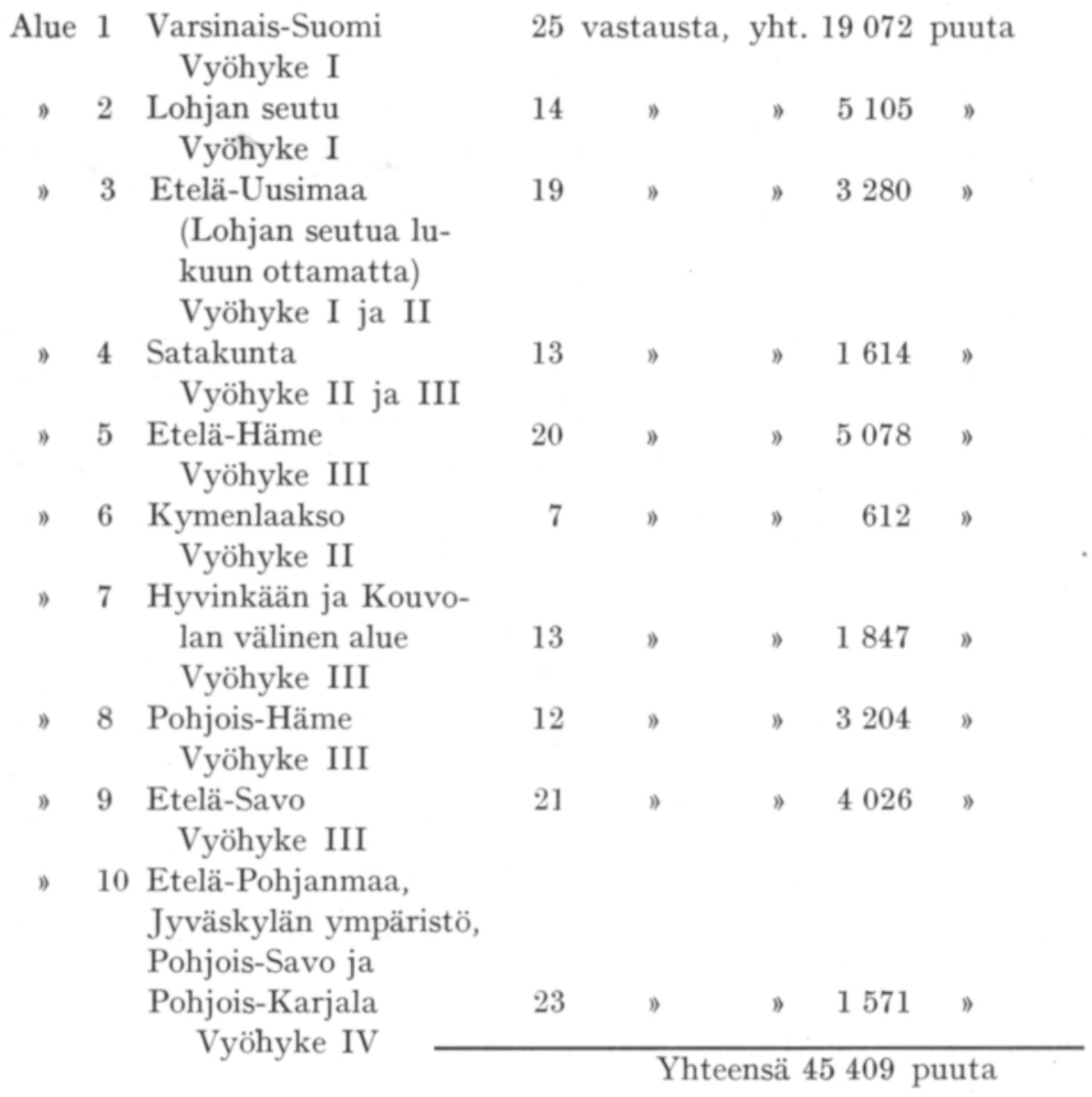

Huom. Mainitut puuluvut tarkoittavat vain omenapuita.

Kultakin alueelta saadut vastaukset ryhmiteltiin maalajin, maaston viettävyyden ja maanpinnan hoitotavan mukaan. Aineistoa käsiteltäessä ilmeni, ettei erilaisten ojitusten eikä myöskään tuulensuojan vaikutusta voida selvittää tämän aineiston perusteella. Niin ikään lannoituksesta ja kastelusta annetut tiedot ovat siksi niukkoja ja epämääräisiä, etteivät ne anna aihetta tilastovertailuun. 


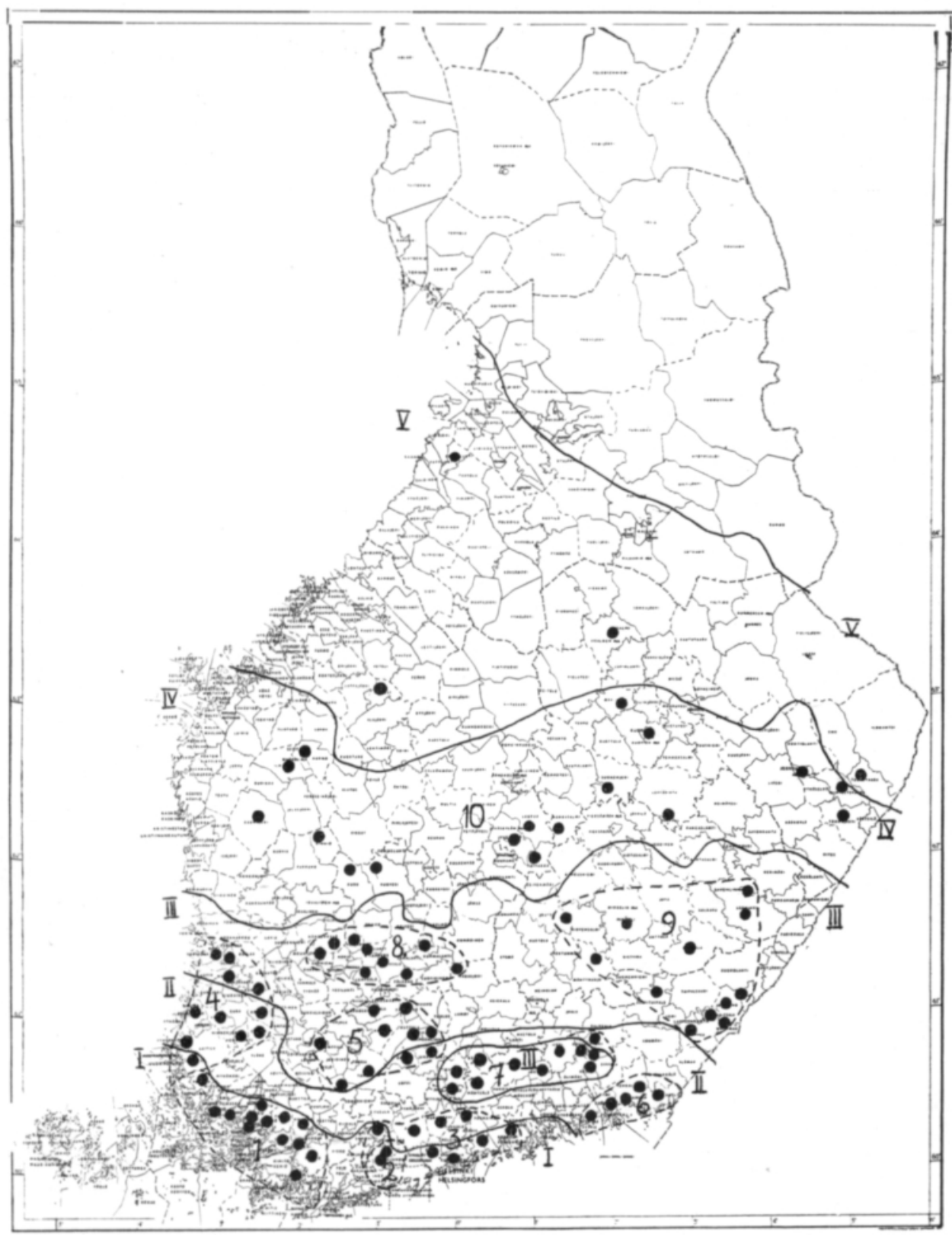

Kuva 1. Vastausaineiston ryhmittely alueisiin ja nykyiset hedelmänviljelyvyöhykkeet. Paikkakunnat, joilta vastauksia on saatu, on merkitty mustilla pisteillä.

Fig. 1. The grouping into regions of the material contained in the questionnaire replies, and the present fruit farming zones. Black dots indicate the localities from which replies have been obtained.

= Hedelmäviljelyvyöhykkeiden rajat Boundaries of the fruit farming zones

= Niiden alueiden rajat, joilta saadut talvehtimistiedot on käsitelty yhdessä ryhmãssä Boundaries of the regions from which the data have been grouped together 
Taulukko 3. Tietoja omenapuiden talvehtimisesta alueilla 1,2 ja 3 .

Table 3. Data on the hibernation of apple-trees in regions 1,2 ja 3.

\begin{tabular}{|c|c|c|c|c|c|c|c|c|c|c|c|c|}
\hline \multirow{2}{*}{$\begin{array}{l}\text { Lajike } \\
\mathrm{a}=\text { alle } 5 \mathrm{v} \text {. } \\
\mathrm{b}=5 \mathrm{v} \text {. ja vanhemmat } \\
\text { Variety } \\
a=\text { Trees less than } 5 \\
\text { years old } \\
b=5 \text {-year-olds and older }\end{array}$} & \multicolumn{4}{|c|}{$\begin{array}{l}\text { Alue } 1 \text { Region } \\
\text { Varsinais-Suomi }\end{array}$} & \multicolumn{4}{|c|}{$\begin{array}{l}\text { Alue } 2 \text { Region } \\
\text { Lohjan seutu }\end{array}$} & \multicolumn{4}{|c|}{$\begin{array}{c}\text { Alue } 3 \text { Region } \\
\text { Etelä-Uusimaa (lukuun ot- } \\
\text { tamatta Lohjan seutua) }\end{array}$} \\
\hline & 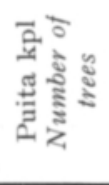 & 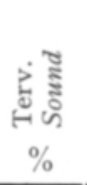 & 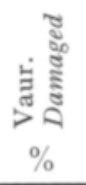 & 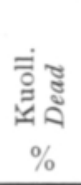 & 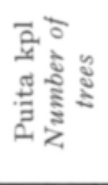 & 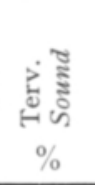 & 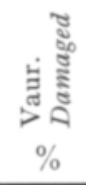 & 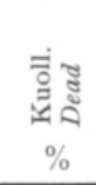 & 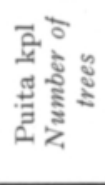 & 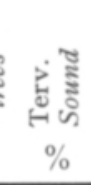 & 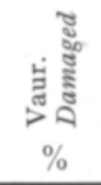 & 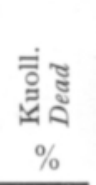 \\
\hline Huvitus $\ldots \ldots \ldots$ a & 107 & 54.9 & 42.6 & 2.5 & & & & & & & & \\
\hline b & 63 & 88.7 & 7.0 & 4.3 & & & & & & & & \\
\hline Valkea kuulas $\ldots$. a & 207 & 73.9 & 18.4 & 7.7 & 411 & 89.5 & 7.3 & 3.2 & 79 & 26.6 & 20.2 & 53.2 \\
\hline Tranparente bl.... b b & 413 & 57.1 & 37.5 & 5.3 & 190 & 89.5 & 6.3 & 4.2 & 33 & 81.8 & 18.2 & 0 \\
\hline Rupert $\ldots \cdots \cdots \cdots \cdot$ a & $\begin{array}{l}52 \\
54\end{array}$ & $\begin{array}{l}96.1 \\
53.7\end{array}$ & $\begin{array}{r}1.9 \\
46.3\end{array}$ & $\begin{array}{l}2.0 \\
0\end{array}$ & & & & & & & & \\
\hline $\begin{array}{ll}\text { Sokeri Miron } . . . . & \text { a } \\
& b\end{array}$ & 26 & 76.9 & 15.4 & 7.7 & & & & & & & & \\
\hline $\begin{array}{ll}\text { Snygg } \ldots \ldots \cdots \cdots & \mathbf{a} \\
& \mathbf{b}\end{array}$ & 54 & 63.0 & 37.0 & 0 & & & & & & & & \\
\hline Lavia $\ldots \ldots \cdots \cdots$ a & $\begin{array}{r}88 \\
322\end{array}$ & $\begin{array}{l}35.2 \\
65.8\end{array}$ & $\begin{array}{l}62.5 \\
33.2\end{array}$ & $\begin{array}{l}2.3 \\
1.0\end{array}$ & 147 & 61.2 & 21.8 & 17.0 & & & & \\
\hline $\begin{array}{lll}\text { Sävstaholm } & \cdots \cdots & \mathbf{a} \\
& & \mathbf{b}\end{array}$ & 166 & 34.9 & 63.2 & 1.9 & 18 & 100.0 & 0 & 0 . & & & & \\
\hline Bergius $\ldots \cdots \cdots \cdots \cdot$ a & $\begin{array}{r}44 \\
285\end{array}$ & $\begin{array}{l}63.6 \\
65.3\end{array}$ & $\begin{array}{l}18.2 \\
31.6\end{array}$ & $\begin{array}{r}18.2 \\
3.1\end{array}$ & $\begin{array}{r}42 \\
110\end{array}$ & $\begin{array}{l}76.2 \\
94.5\end{array}$ & $\begin{array}{r}23.8 \\
5.5\end{array}$ & $\begin{array}{l}0 \\
0\end{array}$ & $\begin{array}{l}46 \\
45\end{array}$ & $\begin{array}{l}82.6 \\
86.9\end{array}$ & $\begin{array}{r}10.9 \\
4.2\end{array}$ & $\begin{array}{l}6.5 \\
8.9\end{array}$ \\
\hline 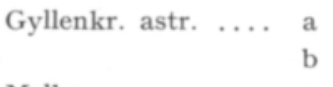 & & & & & 62 & 48.4 & 48.4 & 3.2 & & & & \\
\hline Melba $\ldots \ldots \ldots \cdots \cdot$ a & $\begin{array}{l}342 \\
421\end{array}$ & $\begin{array}{l}82.2 \\
72.0\end{array}$ & $\begin{array}{l}14.0 \\
24.5\end{array}$ & $\begin{array}{l}3.8 \\
3.5\end{array}$ & 73 & 87.7 & 12.3 & 0 & $\begin{array}{l}53 \\
80\end{array}$ & $\begin{array}{l}26.4 \\
43.7\end{array}$ & $\begin{array}{l}22.7 \\
45.0\end{array}$ & $\begin{array}{l}50.9 \\
11.3\end{array}$ \\
\hline Oranie $\quad \cdots \cdots \cdots \cdot \quad \begin{array}{c}\mathbf{a} \\
\end{array}$ & 28 & 7.1 & 75.0 & 17.9 & 31 & 0 & 96.8 & 3.2 & & & & \\
\hline Joyce $\cdots \cdots \cdots \cdots \cdot$ a & 41 & 26.8 & 70.7 & 2.5 & & & & & $\begin{array}{l}33 \\
17\end{array}$ & $\begin{array}{l}12.1 \\
70.6\end{array}$ & $\begin{array}{r}3.4 \\
23.5\end{array}$ & $\begin{array}{r}84.5 \\
5.9\end{array}$ \\
\hline $\begin{array}{rr}\text { Syysjuovikas } \ldots \ldots & \text { a } \\
\text { b }\end{array}$ & $\begin{array}{l}202 \\
336\end{array}$ & $\begin{array}{l}59.4 \\
46.1\end{array}$ & $\begin{array}{l}38.6 \\
49.7\end{array}$ & $\begin{array}{l}2.0 \\
4.2\end{array}$ & 25 & 100.0 & 0 & 0 & 39 & 25.6 & 5.2 & 69.7 \\
\hline Harlamovski $\ldots \ldots$ a & $\begin{array}{r}98 \\
261\end{array}$ & $\begin{array}{l}58.2 \\
32.2\end{array}$ & $\begin{array}{l}39.8 \\
53.2\end{array}$ & $\begin{array}{r}2.0 \\
14.6\end{array}$ & & & & & & & & \\
\hline 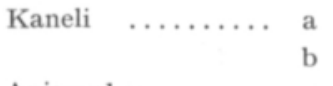 & $\begin{array}{r}490 \\
1123\end{array}$ & $\begin{array}{l}86.5 \\
85.5\end{array}$ & $\begin{array}{l}10.0 \\
12.7\end{array}$ & $\begin{array}{l}3.5 \\
1.8\end{array}$ & 257 & 97.3 & 1.9 & 0.8 & $\begin{array}{l}122 \\
391\end{array}$ & $\begin{array}{r}100.0 \\
91.4\end{array}$ & $\begin{array}{l}0 \\
5.1\end{array}$ & $\begin{array}{l}0 \\
3.5\end{array}$ \\
\hline $\begin{array}{ccc}\text { Anisovska } \ldots \ldots & \text { a } \\
& & b\end{array}$ & 52 & 71.1 & 19.2 & 9.7 & 15 & 100.0 & 0 & 0 & & & & \\
\hline Sariola $\quad \ldots \cdots \cdots \cdots \cdot \begin{array}{c}\mathbf{a} \\
\mathbf{b}\end{array}$ & 120 & 69.2 & 30.0 & 0.8 & & & & & 90 & 84.5 & 11.1 & 4.4 \\
\hline $\begin{array}{rr}\text { Linnan omena } \ldots & \mathbf{a} \\
& \mathbf{b}\end{array}$ & 73 & 60.2 & 37.0 & 2.8 & 408 & 97.8 & 2.0 & 0.2 & & & & \\
\hline Wealthy $\ldots \ldots \ldots$ a & $\begin{array}{l}1794 \\
4558\end{array}$ & $\begin{array}{l}61.2 \\
35.7\end{array}$ & $\begin{array}{l}35.1 \\
49.1\end{array}$ & $\begin{array}{r}3.7 \\
15.2\end{array}$ & $\begin{array}{l}114 \\
458\end{array}$ & $\begin{array}{l}57.9 \\
60.7\end{array}$ & $\begin{array}{l}23.7 \\
13.3\end{array}$ & $\begin{array}{l}18.4 \\
26.0\end{array}$ & $\begin{array}{l}112 \\
445\end{array}$ & $\begin{array}{l}40.2 \\
41.6\end{array}$ & $\begin{array}{r}8.9 \\
27.4\end{array}$ & $\begin{array}{l}50.9 \\
31.0\end{array}$ \\
\hline $\begin{array}{l}\text { Åkerö } \ldots \ldots \ldots \ldots \ldots \\
\end{array}$ & $\begin{array}{ll}1053 \\
2256\end{array}$ & $\begin{array}{l}98.9 \\
50.2\end{array}$ & $\begin{array}{r}1.0 \\
40.3\end{array}$ & $\begin{array}{l}0.1 \\
9.5\end{array}$ & $\begin{array}{l}835 \\
377\end{array}$ & $\begin{array}{l}83.3 \\
80.9\end{array}$ & $\begin{array}{r}7.7 \\
13.8\end{array}$ & $\begin{array}{l}9.0 \\
5.3\end{array}$ & $\begin{array}{l}166 \\
493\end{array}$ & $\begin{array}{l}72.2 \\
77.5\end{array}$ & $\begin{array}{r}3.1 \\
18.2\end{array}$ & $\begin{array}{r}24.7 \\
4.3\end{array}$ \\
\hline
\end{tabular}


Taulukko 4. Tietoja omenapuiden talvehtimisesta alueilla 4, 5 ja 6

Table 4. Data on the hibernation of apple-trees in regions 4, 5 ja 6

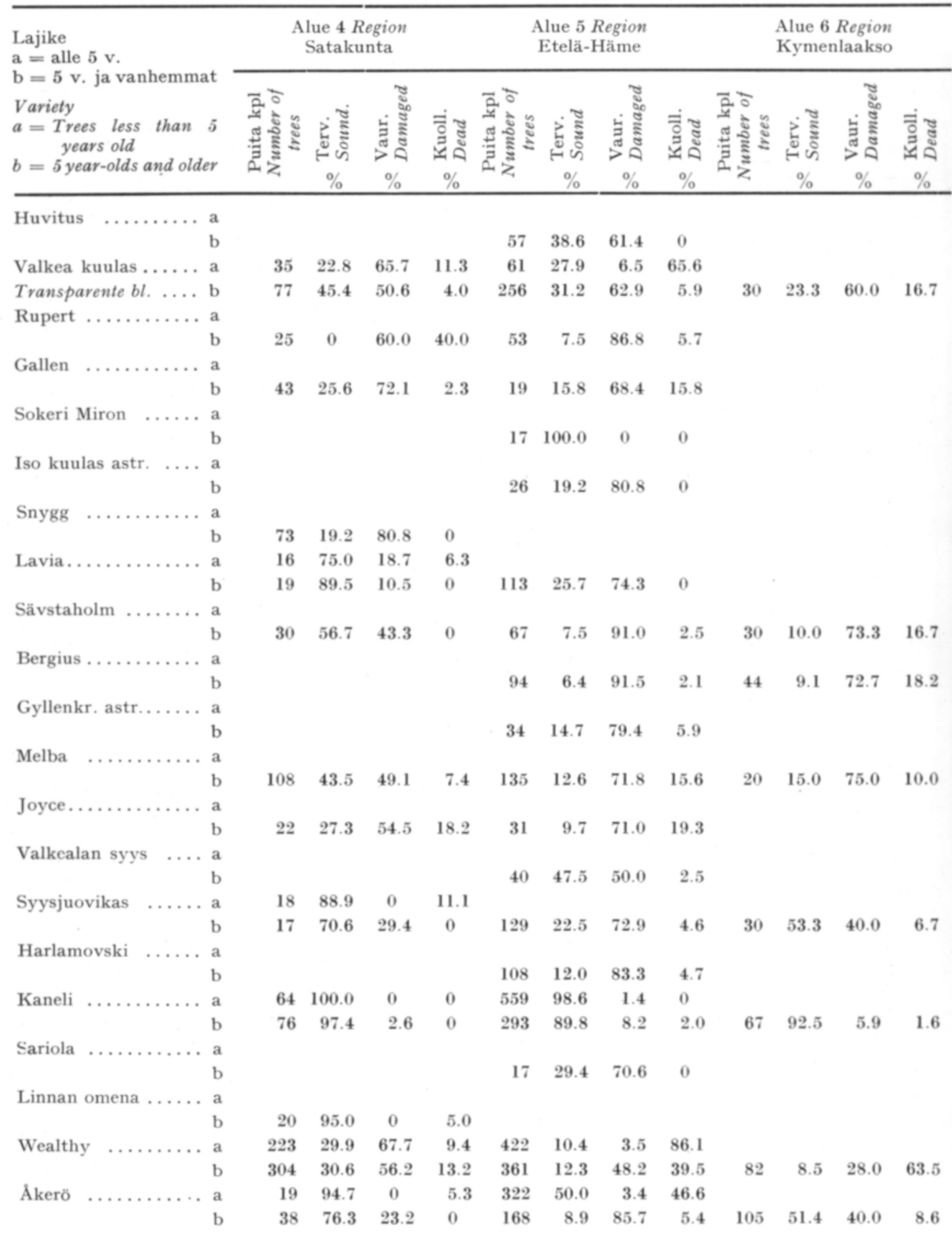




\begin{tabular}{|c|c|c|c|c|c|c|c|c|c|c|c|c|}
\hline \multirow{2}{*}{$\begin{array}{l}\text { Lajike } \\
\mathrm{a}=\text { alle } 5 \mathrm{v} . \\
\mathrm{b}=5 \mathrm{v} . \text { ja vanhemmat } \\
\text { Variety } \\
\begin{array}{c}a=\text { Trees less than } 5 \\
\text { years old }\end{array} \\
b=5 \text { year-olds and older }\end{array}$} & \multicolumn{4}{|c|}{$\begin{array}{l}\text { Alue } 4 \text { Region } \\
\text { Satakunta }\end{array}$} & \multicolumn{4}{|c|}{$\begin{array}{c}\text { Alue } 5 \text { Region } \\
\text { Etelä-Häme }\end{array}$} & \multicolumn{4}{|c|}{$\begin{array}{l}\text { Alue } 6 \text { Region } \\
\text { Kymenlaakso }\end{array}$} \\
\hline & 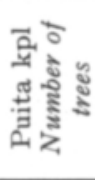 & 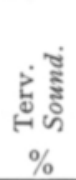 & 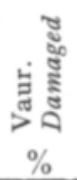 & 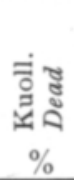 & 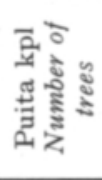 & 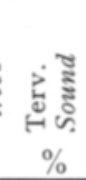 & 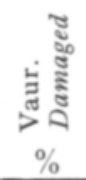 & 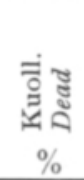 & 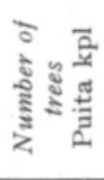 & 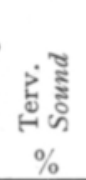 & 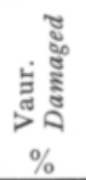 & 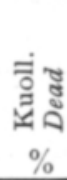 \\
\hline Antonovka $\ldots \ldots \ldots$ a & 23 & 95.6 & 0 & 4.4 & 348 & 28.4 & 6.3 & 65.3 & & & & \\
\hline b & 118 & 73.7 & 22.0 & 4.3 & 310 & 41.6 & 47.4 & 11.0 & 66 & 50.0 & 43.9 & 6.1 \\
\hline Lobo ........... a & 39 & 23.1 & 74.3 & 2.6 & 688 & 11.2 & 68.4 & 20.4 & & & & \\
\hline b & 175 & 12.0 & 77.1 & 10.9 & 116 & 11.2 & 77.6 & 11.2 & 50 & 34.0 & 54.0 & 12.0 \\
\hline Kirkniemi $\quad \ldots \ldots \ldots$ a & & & & & 31 & 100.0 & $\mathbf{0}$ & 0 & & & & \\
\hline Mc Intosh $\ldots \ldots \ldots$ a & & & & & & & & & 17 & 0 & 29.4 & 70.6 \\
\hline
\end{tabular}

tykset koskevat etupäässä kotipuutarhoja. Sitä vastoin Wealthyn heikko talvehtiminen on aiheuttanut huomattavia tappioita, sillä se on ollut eniten viljelty lajike koko maassa. Sama koskee myös Loboa, jonka viljely on viime vuosina voimakkaasti lisääntynyt. Tämä lajike on kuitenkin selviytynyt jonkin verran paremmin kuin Wealthy.

Taulukossa 7 alueittain esitetyt tulokset saattavat olla moneen lajikkeeseen nähden ristiriitaisia niiden kokemuksien kanssa, joita lajikkeiden kestävyydestä on saatu aikaisemmin. On kuitenkin otettava huomioon, etteivät hedelmäpuiden talvenkestävyyttä koskevat tilastot, varsinkaan silloin kun ne on laadittu tiedustelujen pohjalla, yleensä anna täysin luotettavaa kuvaa lajikkeiden kestävyyssuhteista. Tämä johtuu siitä, että on vaikeaa saada aineisto, joka täysin edustaa eri alueiden olosuhteita. Niinpä Collan (2) selvittäessään talven 1928-29 hedelmäpuille aiheuttamia tuhoja totesi tiedustelulla kerätyn aineiston niin epämääräiseksi, ettei ryhtynyt sitä lainkaan tilastoimaan. Tulosten epätasaisuutta lisännee myös se, että havainnontekijöitä on paljon - tässäkin tapauksessa lähes 200 henkilöä -, jolloin arvosteluperusteissa voi esiintyä melkoisia poikkeuksia. Näin ollen onkin tämänlaatuisen tilaston antamia tuloksia pidettävä etupäässä vain suuntaa antavina.

Päärynä-, luumu- ja kirsikkapuista kertynyt aineisto osoittautui niin vähäiseksi, ettei sen esittäminen alueittain vastaa tarkoitustaan. Päärynäpuut ovat yleensä talvehtineet heikosti. Pahimmin näyttää kärsineen Flemish Beauty. Jonkin verran paremmin ovat selviytyneet $\mathrm{mm}$. Elokuun päärynä ja Esperens, mutta näidenkin kuolleisuus on ollut huomattavan suuri.

Luumupuista on saatu tietoja pääasiallisesti neljästä lajikkeesta, nimittäin Yleisestä keltaluumusta, Yleisestä punaluumusta, Victoriasta ja Reine Claude d'Oullinsista. Näistä kaksi ensiksi mainittua ovat talvehtineet paremmin kuin muut. 
Taulukko 5. Tietoja omenapuiden talvehtimisesta alueilla 7,8 ja 9 .

Table 5. Data on the hibernation of apple-trees in regions 7,8 ja 9.

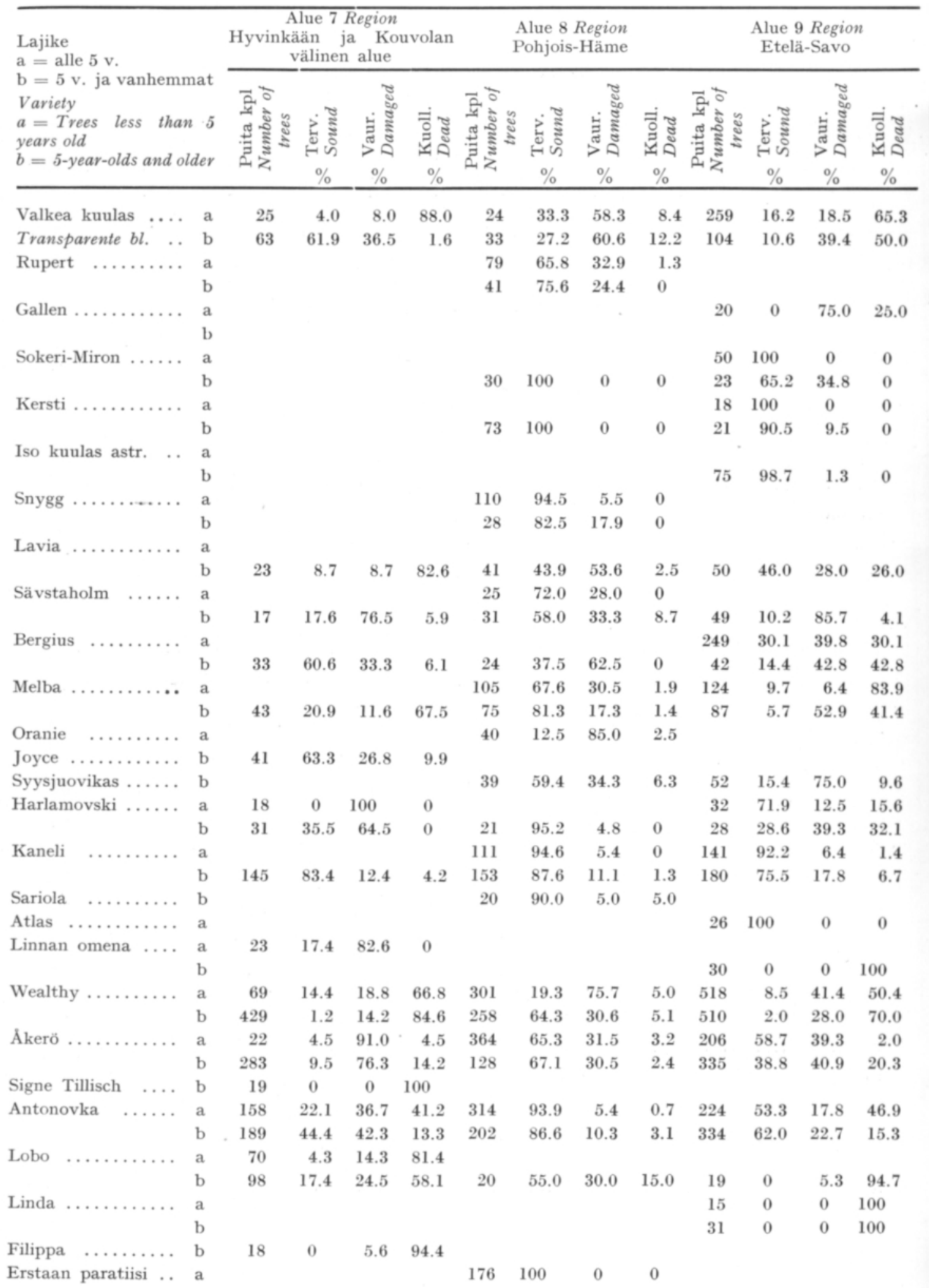


Taulukko 6. Tietoja omenapuiden talvehtimisesta alueella 10 (IV-hedelmånviljelyvyöhyke).

Table 6. Data on the hibernation of apple-trees in region 10 (fruit farming zone IV).

\section{Lajike}

\begin{tabular}{|c|c|c|c|c|}
\hline $\begin{array}{l}a=\text { alle } 5 \mathrm{v} . \text { puut } \\
\mathrm{b}=5 \mathrm{v} . \text { ja vanhemmat puut }\end{array}$ & Puita & Terveitä & Vaurioituneita & Kuolleita \\
\hline Variety & Number & Sound & Damaged & Dead \\
\hline $\begin{array}{l}a=\text { trees less than } 5 \text { years old } \\
b=5 \text {-year-olds and older }\end{array}$ & of trees & $\%$ & $\%$ & $\%$ \\
\hline
\end{tabular}

\begin{tabular}{|c|c|c|c|c|c|}
\hline Valkea kuulas & b & 38 & 5.3 & 23.7 & 71.0 \\
\hline \multicolumn{6}{|l|}{ Transparente bl. } \\
\hline Rupert & b & 17 & 5.9 & 94.1 & 0 \\
\hline Valkea nalif & b & 15 & 53.3 & 33.3 & 13.4 \\
\hline \multirow{2}{*}{ Sokeri Miron } & a & 35 & 5.7 & 45.7 & 48.6 \\
\hline & b & 19 & 26.3 & 42.1 & 31.6 \\
\hline \multirow[t]{2}{*}{ Lavia } & a & 19 & 5.3 & 42.1 & 52.6 \\
\hline & b & 16 & 6.2 & 25.0 & 68.8 \\
\hline \multirow[t]{2}{*}{ Melba } & a & 47 & 0 & 0 & 100.0 \\
\hline & b & 46 & 0 & 34.8 & 65.2 \\
\hline \multirow[t]{2}{*}{ Valkealan syys } & a & 44 & 11.4 & 86.4 & 2.2 \\
\hline & b & 25 & 8.0 & 28.0 & 64.0 \\
\hline Syysjuovikas & b & 27 & 3.7 & 63.0 & 33.3 \\
\hline Harlamovski & b & 48 & 6.2 & 29.2 & 64.6 \\
\hline \multirow[t]{2}{*}{ Kaneli } & a & 72 & 44.4 & 37.5 & 18.1 \\
\hline & b & 321 & 13.4 & 12.1 & 74.5 \\
\hline \multirow[t]{2}{*}{ Wealthy } & a & 81 & 0 & 13.6 & 86.4 \\
\hline & b & 41 & 0 & 31.7 & 68.3 \\
\hline \multirow[t]{2}{*}{ Âkerö } & a & 34 & 0 & 76.5 & 23.5 \\
\hline & b & 80 & 5.0 & 36.2 & 58.8 \\
\hline \multirow[t]{2}{*}{ Antonovka } & $\mathbf{a}$ & 182 & 17.6 & 33.5 & 48.9 \\
\hline & b & 47 & 2.1 & 42.5 & 55.4 \\
\hline Kaikuvuori & a & 25 & 0 & 0 & 100.0 \\
\hline Lobo & b & 48 & 4.2 & 41.7 & 54.1 \\
\hline Erstan paratiisi & a & 24 & 79.2 & 20.8 & 0 \\
\hline Dolgo. & b & 15 & 80.0 & 20.0 & 0 \\
\hline
\end{tabular}

Kirsikkapuista tulleet tiedot koskevat enimmäkseen Yleinen kuulasmarja-, Ostheimer- ja Varjomorelli-lajikkeita. Ahtialan hedelmätarhassa Kirkniemellä ne talvehtivat seuraavasti:

$\begin{array}{lcccc} & \text { Yht. puita } & \text { Terveitä } & \text { Vaurioituneita } & \text { Kuolleita } \\ & \text { kpl } & \% & \% & \% \\ \text { Yleinen kuulasmarja } & 82 & 35.4 & 4.9 & 59.7 \\ \text { Ostheimer } & 31 & 74.2 & 22.6 & 3.2 \\ \text { Varjomorelli } & 91 & 39.6 & 19.8 & 40.6\end{array}$

\section{Omenapuun talvehtiminen Suomen eri alueilla}

Omenapuun talvehtimista eri alueilla voidaan parhaiten tarkastella taulukosta 8. Siinä esitetään terveinä säilyneiden Wealthy- ja Åkerö-puiden prosenttimäärät. Näitä lajikkeita on viljelty eniten miltei kaikkialla. 
Taulukko 7. Yhdistelmä omenapuulajikkeiden talvehtimisesta eri alueilla

$++=$ Hyvin talvehtineet (terveitä $75-100 \%$, kuolleita vähemmän kuin $5 \%$ )

$+=$ Kohtalaisesti talvehtineet (terveitä $50-74.9 \%$, kuolleita vähemmän kuin $15 \%$ )

$+=$ Heikonlaisesti talvehtineet (terveitä 25-49.9\%, kuolleita vähemmän kuin $30 \%$ )

$-=$ Huonosti talvehtineet (terveitä $0-24.9 \%$ )

Huom. Jaottelussa on päähuomio kiinnitetty terveinä säilyneisiin puihin. Mikäli kuolleiden puiden osuus on ylittänyt luokassa sallitun enimmäismäärän, lajike on viety alempiin luokkiin. Sulkumerkeillä varustetuissa merkinnöissä on puiden lukumäärä alle 15:n.

Table 7. Synopsis of the data relating to the hibernation of various apple-tree varieties in the different regions.

+++ Well-hibernated (sound: $75-100 \%$, dead: less than $5 \%$ )

$+=$ Moderately well-hibernated (sound: 50-74.9\%, dead: less than $15 \%$ )

$+=$ Poorly hibernated (sound: $25-49.9 \%$, dead: less than $30 \%$ )

- = Badly hibernated (sound: 0-24.9\%)

Note: In the classification, attention has been paid primarily to the number of the sound trees. If the number of the dead trees exceeded the maximum precentage allowed for the group thus determined, the variety has referred to lower groups. Brackets indicate that the number of trees was less than 15.

Alueet - Regions

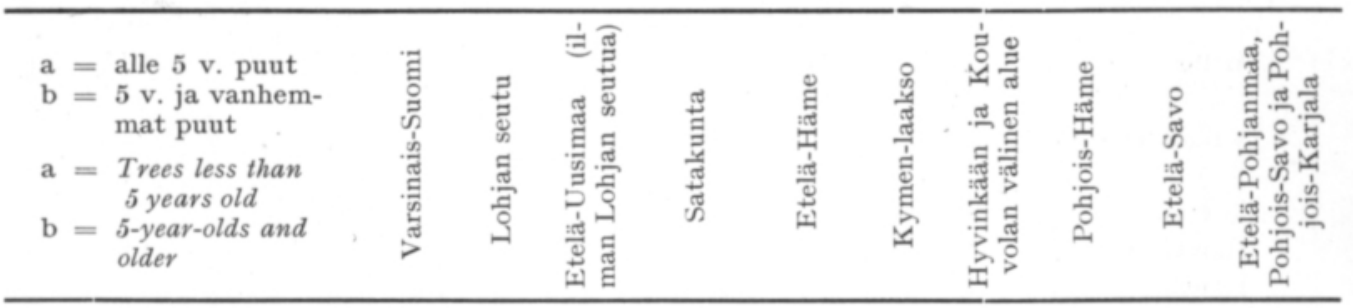

Kesälajikkeet

Summer varietis

Huvitus

Valkea kuulas $\quad$ a

Transparante bl. $\quad \mathrm{b}$

Rupert

a

Gallen

a

Sokeri-Miron

$(+)$

b

Kersti

$$
\begin{array}{rrrr}
++ & (++) & & (++) \\
++ & & (++) & (++) \\
++ & +++ & - & - \\
++ & +++ & ++ & + \\
++ & & & - \\
++ & & &
\end{array}
$$

Iso kuulas astr. a

Snygg

$$
(+++)
$$

$(+++)(+++)$

Lavia

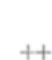

$(+++)$

$++$

Sävstaholm

a

Bergius

Gyllenkrok

(t)
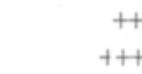

Melba 


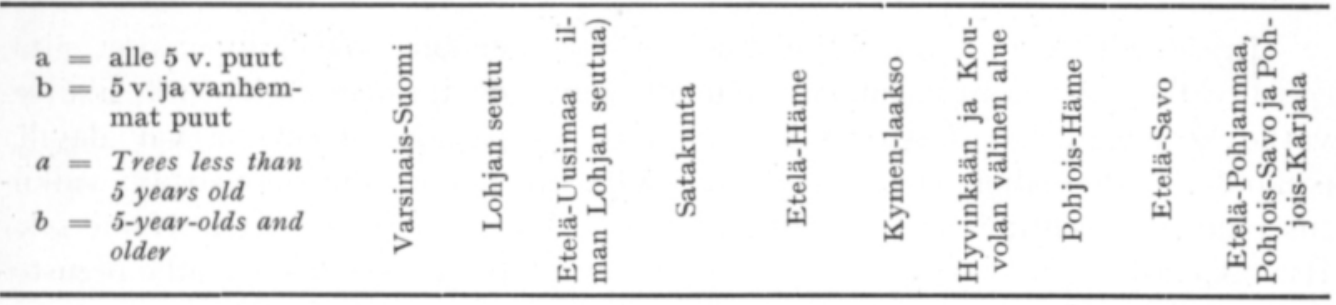

Syyslajikkeet

Autumn varieties

Oranie a

Joyce

Valkealan syys a

Syysjuovikas

Harlamovski

Kaneli

Anisovka

Sariola

Atlas

b

,

$\mathrm{a}$

a

b

a ++

b

a

b

a

Linnan omena

Talvilajikkeet

Winter varieties

Wealthy

Åkerö

Signe Tillisch

Antonovka

Lobo

Linda

Filippa

Kirkniemi

Cox Pomona

Cellini

H. Gylling

$\begin{array}{ll}\text { a } & (++) \\ \text { b } & \end{array}$
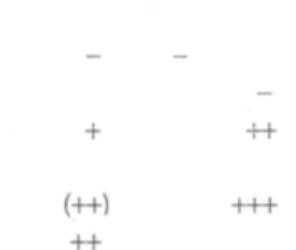

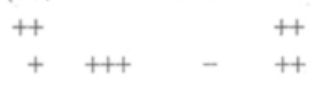$$
+
$$$$
+
$$$$
++
$$$$
+++1+
$$

$+++++$

$++++$

$++t+$

$++$

$++$

$+(++H)$

(+) + +H

$++$

$$
\text { (+1+) }
$$

$+$ $++$

$\begin{array}{llll}\text { a } & \text { b } & \text { H+ } & (++)\end{array}$


Eri alueilta saadut talvehtimistulokset ovat ainakin osaksi riippuvaiset siitä, edustavatko vastaukset enemmän savimaita kuin kevyitä maita sekä siitä, sijaitsevatko hedelmätarhat, joista tiedot on saatu, etupäässä rinnemailla vai alavilla paikoilla. Kuten jäljempänä selvitetään, näillä seikoilla on ollut huomattava vaikutus puiden talvehtimiseen. Alueilta 1,5 ja 7 (Varsinais-Suomi, Etelä-Häme sekä Hyvinkään ja Kouvolan välinen alue) on tiedot etupäässä saatu savimaille perustetuista hedelmätarhoista, kun taas alueilta 2, 4, 6, 8, 9 ja 10 (Lohjan seutu, Satakunta, Kymenlaakso, Pohjois-Häme, Etelä-Savo, Etelä-Pohjanmaa, Pohjois-Savo ja Pohjois-Karjala) on tietoja saatu enimmäkseen hiekka-, hieta- ja hiesumailla sijaitsevista viljelyksistä. Alueelta 3 saaduista vastauksista n. puolet koskee savimaita.

Edellä esitetyt seikat ovat erityisesti Varsinais-Suomessa vaikuttaneet hyvin selvästi talvehtimiseen. Tarkasteltaessa tuloksia koko aineiston perusteella, kasvupaikkaolosuhteita erittelemättä, talvehtiminen on tällä alueella ollut huomattavasti heikompaa kuin Lohjan seudulla (alue 2). Jos sen sijaan verrataan viettäviä hiekka-, hieta- ja hiesumaita koskevia tietoja, mainittujen alueiden välillä ei voida havaita selvää eroa.

Varsin erilaista talvehtiminen on ollut kolmannen hedelmänviljelyvyöhykkeen alueilla 5 ja 8 . Näistä alueista on tässä käytetty nimitystä Etelä-Häme ja Pohjois-

Taulukko 8. Terveinä säilyneiden Wealthy- ja Åkerö-puiden prosenttimäärät alueittain.

Table 8. The percentages of sound Wealthy and Akerö trees, according to region.

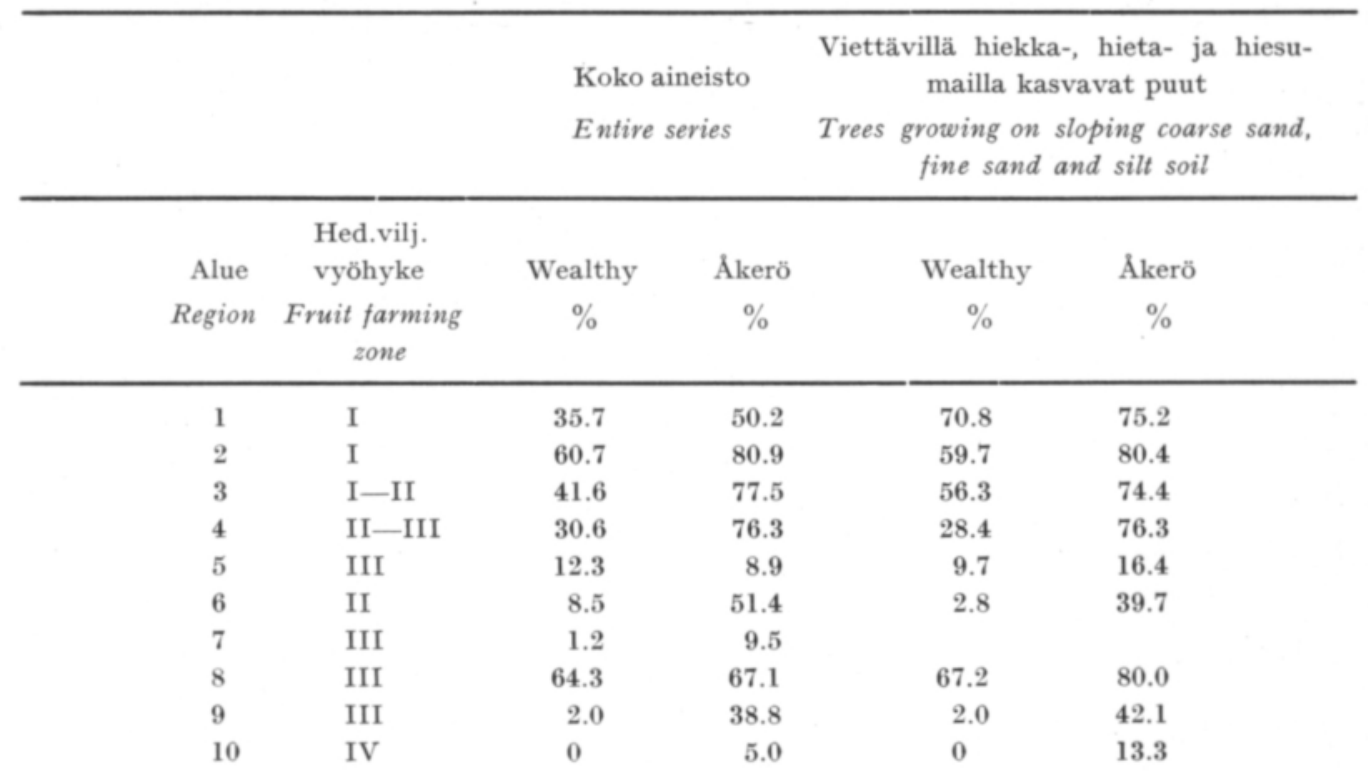

Huom. Taulukossa esitetyt tiedot koskevat 5-vuotiaita ja sitä vanhempia puita. Alueelta 7 on saatu tietoja vain savimaalla kasvavista puista.

Note: The data in this table refer to 5-year-old and older trees. In region 7 information relating only to trees growing on clay soil is available. 


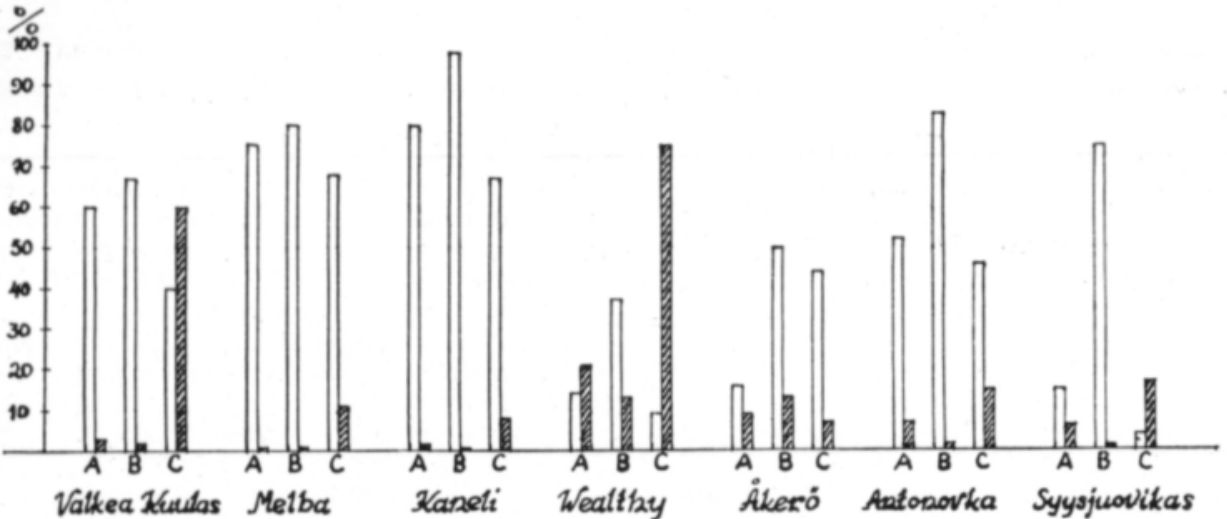

Kuva 2. Omenapuiden talvehtiminen savimaassa alueilla 1, 2 ja 3.
A. Maasto alavaa, maa mulloksella
B. Maasto viettäväã, maa mulloksella
C. Maasto viettävää, maa nurmena

Valkoiset pylvăăt esittăvăt terveiden puiden ja viivoitetut kuolleiden puiden prosenttimäărää.

Fig. 2. The hibernation of apple-trees on clay soil in regions 1, 2 and 3.
A. Low-lying terrain, open soil
B Sloping terrain, open soil
C Sloping terrain, grass-land

The white columns represent the percentage of sound trees, the shaded columns that of dead trees.

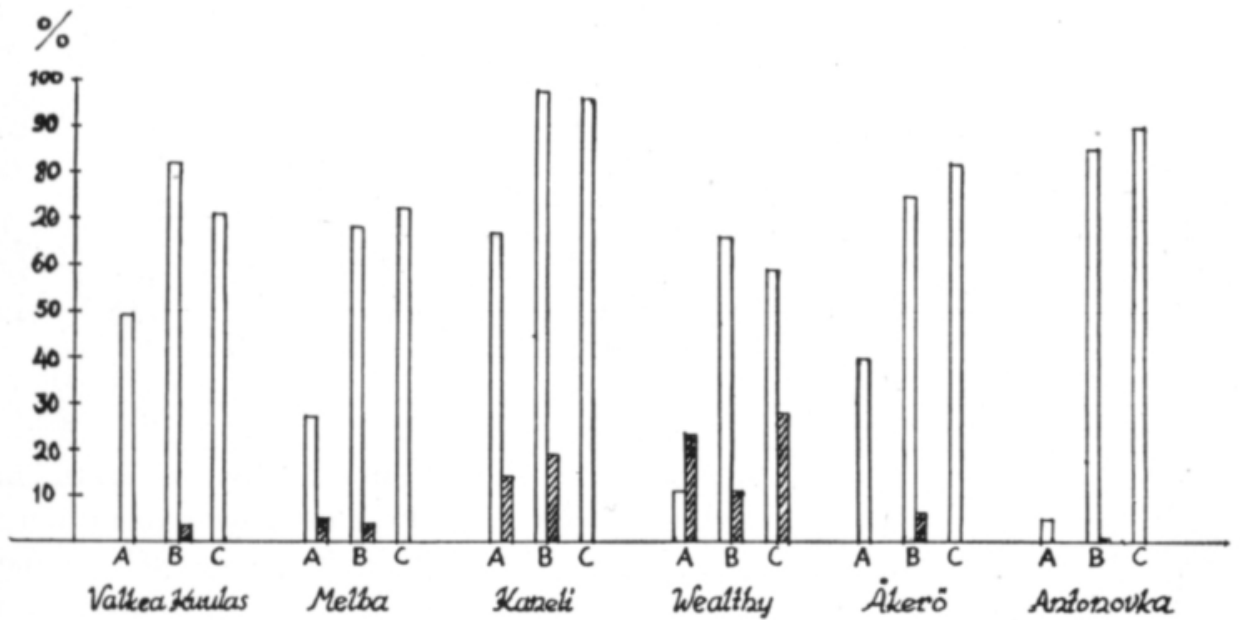

Kuva 3. Omenapuiden talvehtiminen kevyissä maissa alueilla 1, 2 ja 3.
A Maasto alavaa, hiekka- ja hietamaa, maa mulloksella
B Maasto viettåvăă, hiekka- ja hietamaa, maa mulloksella
C Maasto viettävää, hiesumaa, maa mulloksella

Valkoiset pylväät esittävät terveinä säilyneiden ja viivoitetut kuolleiden puiden prosenttimääräă.

Fig. 3. The hibernation of apple-trees on light soils in regions 1, 2 and 3.
A Coarse and fine sand soil, low-lying terrain, open soil
$B$ Coarse and fine sand soil, sloping terrain, open soil

C Silt soil, sloping terrain, open soil

The white columns represent the percentage of sound trees, the shaded columns that of dead trees. 
Taulukko 9. Kasvupaikan ja maalajin vaikutus omenapuiden talvehtimiseen. Tiedot alueilta 1,2 ja 3.

Table 9. The influence of site of growth and of soil type upon the hibernation of apple-trees. Data from regions 1,2 and 3 .

\begin{tabular}{|c|c|c|c|c|c|c|c|c|c|c|}
\hline \multirow{2}{*}{\multicolumn{2}{|c|}{$\begin{array}{l}\text { Lajike } \\
\begin{aligned} \mathrm{a}= & \text { alle } 5 \mathrm{v} \text {. puut } \\
\mathrm{b}= & 5 \mathrm{v} . \text { ja vanhem- } \\
& \text { mat puut }\end{aligned} \\
\text { Variety } \\
\mathrm{a}=\text { Trees less than } \\
5 \text { years old } \\
\mathrm{b}=5 \text {-year-olds and } \\
\quad \text { older }\end{array}$}} & \multicolumn{3}{|c|}{$\begin{array}{c}\text { Savimaa, maasto alavaa, } \\
\text { maa mulloksella } \\
\text { Clay soil, low-lying } \\
\text { terrain, open soil }\end{array}$} & \multicolumn{3}{|c|}{$\begin{array}{c}\text { Savimaa, maasto viettä- } \\
\text { vää, maa mulloksella } \\
\text { Clay soil, sloping terrain, } \\
\text { open soil }\end{array}$} & \multicolumn{3}{|c|}{$\begin{array}{c}\text { Savimaa, maasto viettä- } \\
\text { vää, maa nurmena } \\
\text { Clay soil, sloping terrain, } \\
\text { grass-land }\end{array}$} \\
\hline & & $\begin{array}{c}\text { Puita } \\
\text { kpl } \\
\text { Number } \\
\text { of } \\
\text { trees }\end{array}$ & $\begin{array}{c}\text { Terv. } \\
\text { Sound } \\
\%\end{array}$ & $\begin{array}{c}\text { Kuoll. } \\
\text { Dead } \\
\%\end{array}$ & $\begin{array}{c}\text { Puita } \\
\text { kpl } \\
\text { Number } \\
\text { of } \\
\text { trees }\end{array}$ & $\begin{array}{l}\text { Terv. } \\
\text { Sound } \\
\%\end{array}$ & $\begin{array}{c}\text { Kuoll. } \\
\text { Dead } \\
\%\end{array}$ & $\begin{array}{c}\text { Puita } \\
\text { kpl } \\
\text { Number } \\
\text { of } \\
\text { trees }\end{array}$ & $\begin{array}{l}\text { Terv. } \\
\text { Sound } \\
\%\end{array}$ & $\begin{array}{c}\text { Kuoll. } \\
\text { Dead } \\
\%\end{array}$ \\
\hline \multirow[t]{2}{*}{ Huvitus } & $\mathrm{a}$ & 59 & 1.7 & 8.5 & 144 & 78.5 & 0.7 & & & \\
\hline & b & & & & & & & 28 & 71.4 & 1.1 \\
\hline \multirow{4}{*}{$\begin{array}{l}\text { Valkea kuulas } \\
\text { Transparente } b l . \\
\text { Bergius }\end{array}$} & $\mathrm{a}$ & & & & & & & & & \\
\hline & b & 95 & 60.0 & 3.1 & 199 & 77.4 & 2.0 & 25 & 40.0 & 60.0 \\
\hline & $\mathbf{a}$ & 53 & 71.7 & 3.8 & 76 & 78.9 & 7.9 & & & \\
\hline & b & 43 & 9.3 & 4.6 & 175 & 81.1 & 3.4 & & & \\
\hline \multirow[t]{2}{*}{ Melba } & a & 308 & 89.3 & 1.6 & 36 & 19.4 & 22.2 & & & \\
\hline & b & 143 & 75.5 & 0.7 & 149 & 80.5 & 1.3 & 89 & 68.5 & 11.2 \\
\hline \multirow[t]{2}{*}{ Syysjuovikas } & $\mathrm{a}$ & 49 & 10.2 & 8.2 & 133 & 75.2 & 0 & & & \\
\hline & b & 118 & 15.2 & 5.9 & 164 & 75.0 & 1.2 & 23 & 4.3 & 17.4 \\
\hline \multirow[t]{2}{*}{ Harlamovski } & a & 35 & 14.3 & 5.7 & 60 & 83.3 & 0 & & & \\
\hline & b & 99 & 5.0 & 26.3 & 91 & 53.8 & 11.0 & & & \\
\hline \multirow[t]{2}{*}{ Kaneli } & a & 163 & 85.3 & 1.8 & 393 & 93.1 & 2.8 & & & \\
\hline & b & 262 & 80.5 & 1.5 & 518 & 97.9 & 0.2 & 162 & 66.7 & 8.0 \\
\hline \multirow[t]{2}{*}{ Wealthy } & a & 405 & 15.8 & 17.3 & 1050 & 68.0 & 3.9 & & & \\
\hline & $\mathbf{b}$ & 772 & 14.0 & 21.0 & 2610 & 37.4 & 13.3 & 53 & 9.4 & 75.5 \\
\hline \multirow[t]{2}{*}{ Åkerö } & $\mathbf{a}$ & 133 & 86.5 & 5.3 & 1033 & 97.4 & 2.6 & 35 & 88.6 & 2.8 \\
\hline & b & 347 & 16.4 & 9.2 & 1062 & 49.5 & 13.0 & 155 & 44.5 & 7.1 \\
\hline \multirow[t]{2}{*}{ Signe Tillisch } & $\mathrm{a}$ & 66 & 0 & 97.0 & & & & & & \\
\hline & b & 55 & 0 & 63.6 & 86 & 3.5 & 17.4 & 19 & 0 & 68.4 \\
\hline \multirow[t]{2}{*}{ Antonovka } & $\mathbf{a}$ & 182 & 18.1 & 15.9 & 390 & 80.0 & 3.1 & 51 & 100 & 0 \\
\hline & b & 544 & 52.2 & 7.0 & 413 & 83.3 & 1.4 & 149 & 46.3 & 14.8 \\
\hline \multirow[t]{2}{*}{ Lobo } & $\mathbf{a}$ & 86 & 12.8 & 41.9 & 295 & 43.7 & 17.3 & & & \\
\hline & b & 136 & 16.9 & 39.0 & 1068 & 71.7 & 4.7 & & & \\
\hline
\end{tabular}

Häme. Kuten jo edellä mainittiin, on tiedot ensiksi mainitulta alueelta saatu enimmäkseen savimailta ja jälkimmäiseltä alueelta kevyiltä mailta. Kun verrataan talvehtimista kummallakin alueella yksinomaan viettäviltä hiekka-, hieta- ja hiesumailta saatujen tietojen perusteella, ovat puut niissäkin olosuhteissa menestyneet selvästi heikommin Etelä-Hämeessä kuin Pohjois-Hämeessä. Syy on löydettävissä näiden alueiden erilaisista lämpötiloista talvella 1955-56. Etelä-Hämeestä on käytettävissä tiedot Lepaan ja Pohjois-Hämeestä Pälkäneen säähavaintoasemalla tehdyistä lämpötilanmittauksista. Siitä huolimatta, että kuukausien keskilämpötilat marraskuusta huhtikuuhun pysyttelevät likipitäen yhtäläisinä (taulukko 2), ilmenee näiden havaintopaikkojen lämpötiloissa kuitenkin eroja. Niinpä päivittäin mitattujen pakkasasteitten summa marraskuusta maaliskuuhun, jota käytetään hedelmänviljelyä koskevien tuhotalvien vertailussa (8), on suurempi Lepaalla kuin Pälkäneellä. Tødennäköisesti marraskuun loppupuolen pakkasilla on kuitenkin ollut 
Taul. 9 jatko

Lajike

$\mathrm{a}=$ alle $5 \mathrm{v}$. puut

$\mathrm{b}=5 \mathrm{v}$, ja vanhemmat puut

Variety

$\mathrm{a}=$ Trees less than Puita 5 years old kpl Terv. Kuoll.

$\mathrm{b}=5$-year-olds and Number Sound Dead older
Hiekka- ja hietamaa, maasto alavaa, maa mulloksella

Coarse and fine sand soil, low-lying terrain, open soil

of
trees

$\%$
Hiekka- ja hietamaa, maasto viettävää, maa mulloksella

Coarse and fine sand soil, sloping terrain, open soil

Puita Puita

kpl Terv. Kuoll. kpl Terv. Kuoll. Number Sound Dead Number Sound Dead of $\quad$ of trees $\quad \% \quad \% \quad$ trees
Hiesumaa,

maasto viettävää,

maa mulloksella

Silt soil, sloping terrain, open soil

$\%$

Huvitus

b

Valkea kuulas a

Transparente bl. b

Bergius

Melba

Syysjuovikas

Harlamovski b

Kaneli

Wealthy

Àkerö

$\begin{array}{ll}\text { Signe Tillisch } & \text { b } \\ \text { a } & \text { b }\end{array}$

Antonovka a

Lobo

\begin{tabular}{|c|c|c|c|c|c|c|c|c|}
\hline & & & 40 & 100 & 0 & & & \\
\hline & & & 402 & 92.5 & 3.0 & 18 & 55.5 & 0 \\
\hline 89 & 49.4 & 0 & 227 & 82.4 & 3.5 & 35 & 71.4 & 0 \\
\hline \multirow[t]{2}{*}{31} & 16.1 & 16.1 & 114 & 94.7 & 0 & 31 & 93.5 & 0 \\
\hline & & & & & & 20 & 60.0 & 15.0 \\
\hline \multirow[t]{2}{*}{40} & 27.5 & 5.0 & 28 & 67.8 & 3.6 & 91 & 72.5 & 0 \\
\hline & & & 24 & 79.2 & 0 & & & \\
\hline 34 & 47.0 & 2.9 & 25 & 100 & 0 & & & \\
\hline
\end{tabular}

$\begin{array}{lll}71 & 42.2 & 2.8\end{array}$

$\begin{array}{crrrc} & & & 41 & 100 \\ 139 & 66.9 & 14.4 & 373 & 97.3\end{array}$

$\begin{array}{rrrr}512 & 10.9 & 23.6 & 1240\end{array}$

75.5

1.6

136

$96.3 \quad 0$

$66.4 \quad 11.2$

$\begin{array}{lll}100 & 59.0 & 28.0\end{array}$

$\begin{array}{llll}104 & 40.4 & 0 & 1291\end{array}$

82.6

75.5

9.6

6.6

150

82.0

231

87.9

9.9

$\begin{array}{lll}75 & 46.7 & 26.7\end{array}$

220

5.4

0.4

202

86.6

26.7

a

21

47.6

$172 \quad 100$

$1.0 \quad 50$

31
50
105

$74.2 \quad 16.1$

$90.0 \quad 0$

$97.1 \quad 0$

$\begin{array}{llll}99 & 98.0 & 0 & 33\end{array}$

90.9

6.1

ratkaisevin merkitys. Mainitun kuun 25. ja 26. päivänä on Lepaalla nimittäin mitattu 20.0 ja $21.6^{\circ}$ :n pakkanen, kun sitä vastoin Pälkäneellä on pakkasta ollut vain 14.2 ja $14.0^{\circ}$.

Mainittakoon lisäksi, että Ilmatieteellisen Keskuslaitoksen antamien tietojen mukaan lämpöolot ovat Pälkäneen havaintoasemalla olleet kesäisin 20 vuoden aikana jonkin verran edullisemmat kuin Lepaalla.

\section{Maaston viettävyyden, maalajin ja maanpinnan hoitotavan vaikutus omenapun talvehtimiseen}

Omenapuiden talvehtiminen on ollut alavilla paikoilla selvästi heikompaa kuin rinnemailla (taulukot 9 ja 11, kuvat 2 ja 3). Tämä koskee sekä savimaita että hiekka- ja hietamaita. Käsitystä maaston viettävyyden merkityksestä vahvistaa 
Taulukko 10. Kasvupaikan ja maalajin vaikutus omenapuiden talvehtimiseen. Tiedot alueilta 4,5 ja 8 Table 1o. The influence of site of growth and of soil type upon the hibernation of apple-trees. Data from regions 4,5 and 8 .

\begin{tabular}{|c|c|c|c|c|c|c|c|c|c|c|}
\hline \multirow{3}{*}{\multicolumn{2}{|c|}{$\begin{array}{l}\text { Lajike } \\
\qquad \begin{array}{l}\mathrm{a}=\text { alle } 5 \mathrm{v} \text {. puut } \\
\mathrm{b}=5 \mathrm{v} . \text { vanhemmat } \\
\text { puut }\end{array} \\
\begin{aligned} \text { Variety } \\
\mathrm{a}=\end{aligned} \\
\begin{array}{l}\text { Trees less than } \\
5 \text { years old }\end{array} \\
\mathrm{b}=\begin{array}{l}5 \text {-year-olds and } \\
\text { older }\end{array}\end{array}$}} & \multicolumn{3}{|c|}{$\begin{array}{l}\text { Savimaa, maasto viet- } \\
\text { tävää, maa mulloksella } \\
\text { Clay soil, sloping } \\
\text { terrain, open soil }\end{array}$} & \multicolumn{3}{|c|}{$\begin{array}{l}\text { Hiekka- ja hietamaa, } \\
\text { maasto viettävää, } \\
\text { maa mulloksella } \\
\text { Coarse and fine sand } \\
\text { soil, sloping terrain } \\
\text { open soil }\end{array}$} & \multicolumn{3}{|c|}{$\begin{array}{l}\text { Hiekka- ja hietamaa, } \\
\text { maasto viettävää, } \\
\text { maa nurmena } \\
\text { Coarse and fine sand } \\
\text { soil, sloping terrain, } \\
\text { grass-land }\end{array}$} \\
\hline & & \multirow{2}{*}{$\begin{array}{c}\text { Puita } \\
\text { kpl } \\
\text { Number } \\
\text { of } \\
\text { trees }\end{array}$} & \multicolumn{2}{|c|}{$\begin{array}{l}\text { Terv. Kuoll. } \\
\text { Sound Dead }\end{array}$} & \multirow{2}{*}{$\begin{array}{l}\text { Puita } \\
\text { kpl } \\
\text { Number } \\
\text { of } \\
\text { trees }\end{array}$} & \multirow{2}{*}{$\begin{array}{l}\text { Terv. } \\
\text { Sound } \\
\qquad \%\end{array}$} & \multirow{2}{*}{$\begin{array}{l}\text { Kuoll } \\
\text { Dead } \\
\%\end{array}$} & \multirow{2}{*}{$\begin{array}{c}\text { Puita } \\
\text { kpl } \\
\text { Number } \\
\text { of } \\
\text { trees }\end{array}$} & \multirow{2}{*}{$\begin{array}{c}\text { Terv. } \\
\text { Sound } \\
\%\end{array}$} & \multirow{2}{*}{$\begin{array}{c}\text { Kuoll } \\
\text { Dead } \\
\% \\
\%\end{array}$} \\
\hline & & & $\%$ & $\%$ & & & & & & \\
\hline Huvitus & $\mathbf{b}$ & 45 & 46.7 & 0 & 25 & 24.0 & 0 & & & \\
\hline Valkea kuulas & $\mathrm{a}$ & 58 & 3.4 & 67.0 & 49 & 30.6 & 0 & & & \\
\hline Transparente bl. & b & 157 & 74.5 & 10.8 & 179 & 50.3 & 1.7 & 25 & 40.0 & 4.0 \\
\hline Lavia & $\mathrm{b}$ & 51 & 15.7 & 0 & 95 & 33.7 & 1.0 & 17 & 82.3 & 0 \\
\hline \multirow[t]{2}{*}{ Bergius } & $\mathbf{a}$ & 73 & 4.1 & 2.7 & & & & & & \\
\hline & b & & & & & & & 20 & 60.0 & 0 \\
\hline \multirow[t]{2}{*}{ Melba } & $\mathbf{a}$ & 71 & 12.7 & 22.5 & 114 & 68.4 & 1.7 & & & \\
\hline & b & & & & 189 & 51.8 & 4.2 & 41 & 39.0 & 7.3 \\
\hline Syysjuovikas & b & 93 & 26.9 & 8.6 & 41 & 73.2 & 0 & 50 & 30.0 & 0 \\
\hline Harlamovski & b & 39 & 25.6 & 10.2 & 68 & 2.9 & 1.5 & 21 & 95.2 & 0 \\
\hline \multirow[t]{2}{*}{ Kaneli } & a & 555 & 99.4 & 0 & 98 & 97.9 & 0 & & & \\
\hline & b & 229 & 84.3 & 3.0 & 180 & 93.9 & 0.5 & 100 & 100 & 0 \\
\hline \multirow[t]{2}{*}{ Wealthy } & $\mathrm{a}$ & 372 & 6.4 & 93.5 & 544 & 23.3 & 6.8 & & & \\
\hline & b & 213 & 10.3 & 44.6 & 579 & 43.2 & 9.8 & 115 & 8.7 & 60.0 \\
\hline \multirow[t]{2}{*}{ Åkeró } & $\mathbf{a}$ & 316 & 50.0 & 47.5 & 355 & 65.1 & 3.1 & & & \\
\hline & b & 129 & 10.8 & 6.2 & 142 & 63.4 & 0 & 73 & 58.9 & 4.1 \\
\hline \multirow[t]{2}{*}{ Antonovka } & $\mathbf{a}$ & 306 & 28.1 & 71.9 & 354 & 90.7 & 2.0 & & & \\
\hline & b & 192 & 25.0 & 18.2 & 332 & 78.0 & 1.8 & 92 & 85.7 & 1.1 \\
\hline \multirow[t]{2}{*}{ Lobo } & $\mathbf{a}$ & 679 & 11.0 & 20.6 & 41 & 21.9 & 2.4 & & & \\
\hline & b & 76 & 1.3 & 17.1 & 210 & 15.7 & 9.0 & & & \\
\hline
\end{tabular}

myös se, että alavilla paikoilla puut ovat talvehtineet yhtä heikosti savi-, hiekka- ja hietamailla, kun taas viettävillä kasvupaikoilla hiekka- ja hietamaat ovat olleet talvehtimisen kannalta edullisempia (taulukot 9, 10, 11 ja 12). Maalaji on tässä määritetty jankon mukaan. Alavien kasvupaikkojen epäedullisuus johtunee etupäässä syksyn 1955 runsaiden sateiden vuoksi korkealla pysytelleestä pohjavedestä sekä myös siitä, että alavat paikat yleensä ovat kylmempiä kuin rinnemaat.

Viettävillä hiesumailla on talvehtiminen sujunut likipitäen yhtä hyvin kuin viettävillä hiekka- ja hietamailla (taulukko 9). Alavilla hiesumailla taas on puiden mainittu talvehtineen heikosti.

Näyttää siltä, että puut ovat viettävissä savimaissa säilyneet paremmin kasvaessaan mulloksella kuin nurmena pidetyissä hedelmätarhoissa (taulukko 9 ja kuva 2). Viettävissä hiekkamaissa on eri lajikkeista sen sijaan saatu vaihtelevia tuloksia (taulukko 10). Myös kirjallisuudessa esiintyy tietoja, joiden mukaan puut ovat eri- 
Taulukko 11. Omenpuiden talvehtiminen eri maalajeissa sekä viettävässä että alavassa maastossa Karvetin hedelmätarhassa Naantalissa.

Table 11. The hibernation of apple-trees on different soils, and on sloping and low-lying terrain. Karvetti fruit farm, Naantali.

\begin{tabular}{|c|c|c|c|c|c|c|c|c|}
\hline Lajike & $\begin{array}{l}\text { Puita } \\
\text { kpl }\end{array}$ & $\begin{array}{l}\text { Terveet } \\
\text { ja liev. } \\
\text { vaurioi- } \\
\text { tuneet }\end{array}$ & $\begin{array}{l}\text { Keskin- } \\
\text { kert. } \\
\text { vaurioi- } \\
\text { tuneet }\end{array}$ & $\begin{array}{l}\text { Pahoin } \\
\text { vaurioi- } \\
\text { tuneet ja } \\
\text { kuolleet }\end{array}$ & $\begin{array}{l}\text { Puita } \\
\text { kpl }\end{array}$ & $\begin{array}{l}\text { Terveet } \\
\text { ja liev. } \\
\text { vaurioi- } \\
\text { tuneet }\end{array}$ & $\begin{array}{l}\text { Keskin- } \\
\text { kert. } \\
\text { vaurioi- } \\
\text { tuneet }\end{array}$ & $\begin{array}{c}\text { Pahoin } \\
\text { vaurioi- } \\
\text { tuneet ja } \\
\text { kuolleet }\end{array}$ \\
\hline Variety & $\begin{array}{c}\text { Number } \\
\text { of } \\
\text { trees }\end{array}$ & $\begin{array}{c}\text { Sound and } \\
\text { slightly } \\
\text { damaged } \\
\%\end{array}$ & $\begin{array}{c}\text { Moderately } \\
\text { damaged } \\
\%\end{array}$ & $\begin{array}{c}\text { Badly } \\
\text { damaged } \\
\text { and dead } \\
\%\end{array}$ & $\begin{array}{c}\text { Number } \\
\text { of } \\
\text { trees }\end{array}$ & $\begin{array}{c}\text { Sound and } \\
\text { slightly } \\
\text { damaged } \\
\%\end{array}$ & $\begin{array}{c}\text { Moderately } \\
\text { damaged } \\
\%\end{array}$ & $\begin{array}{c}\text { Badly } \\
\text { damaged } \\
\text { and dead } \\
\%\end{array}$ \\
\hline
\end{tabular}

Hiekkamaa, maasto loiv. viettävää, pui- Savimaa, maasto loiv. viettãväă, puiden ikä $15 \mathrm{v}$. den ikä $15 \mathrm{v}$.

Coarse sand soil, gradually sloping terrain. Clay soil, gradually sloping terrain. Age of Age of trees: 15 years

\begin{tabular}{|c|c|c|c|c|c|c|c|c|}
\hline Lavia ........ & 193 & 85.5 & 11.4 & 3.1 & 115 & 73.0 & 20.1 & 6.9 \\
\hline Bergius ...... & 27 & 63.0 & 29.6 & 7.4 & 41 & 51.2 & 26.9 & 21.9 \\
\hline$\ldots \ldots$ & 40 & 82.5 & 7.5 & 10.0 & 33 & 78.8 & 18.2 & 3.0 \\
\hline Syysjuovikas . & 33 & 97.0 & 3.0 & 0 & 71 & 57.7 & 32.5 & 9.8 \\
\hline Harlamovski. & 71 & 92.9 & 1.5 & 5.6 & 47 & 72.3 & 14.9 & 12.8 \\
\hline Kaneli ..... & 139 & 93.5 & 4.4 & 2.1 & 120 & 96.7 & 2.5 & 0.8 \\
\hline Wealthy $\ldots$. & 512 & 29.7 & 40.2 & 30.1 & 57 & 29.8 & 14.1 & 56.1 \\
\hline Ákerö $\quad \ldots .$. & 104 & 77.9 & 17.3 & 4.8 & 35 & 77.1 & 11.5 & 11.4 \\
\hline Antonovka .. & 220 & 73.6 & 25.0 & 1.4 & 97 & 80.4 & 16.5 & 3.1 \\
\hline
\end{tabular}

Savimaa, maasto loiv. viettävää, puiden Savimaa, maasto alavaa, puiden ikä ikä $6-8 \mathrm{v}$.

$$
6-8 \mathrm{v} \text {. }
$$

Clay soil, sloping terrain. Age of trees: Clay soil, low-lying terrain. Age of tree:s $6-8$ years $6-8$ years

$\begin{array}{lrrrrrrrr}\text { Syysjuovikas . } & \mathbf{7 4} & \mathbf{8 7 . 8} & 8.2 & 4.0 & 32 & 34.4 & 34.4 & 31.2 \\ \text { Harlamovski . } & 52 & 53.8 & 15.4 & 30.8 & 21 & 38.1 & 19.1 & 42.8 \\ \text { Wealthy . . . } & 1058 & 73.1 & 20.1 & 6.8 & 527 & 20.9 & 29.0 & 50.1 \\ \text { Åkerö . . . . . } & 129 & 51.2 & 23.2 & 25.6 & 130 & 15.4 & 26.9 & 57.7 \\ \text { Signe Tillisch . } & 86 & 17.4 & 61.6 & 44.7 & 46 & 0 & 8.7 & 91.3 \\ \text { Lobo . . . . . . . } & 265 & 62.3 & 17.3 & 20.4 & 116 & 7.7 & 22.5 & 69.8\end{array}$

Savimaa, maasto loiv. viettävää, pui- Savimaa, maasto alavaa, puiden ikä den ikä $3-5 \mathrm{v}$. $3-5 \mathrm{v}$.

Clay soil, gradually sloping terrain. Age Clay soil, low-lying terrain. Age of trees: of trees: $3-5$ years $3-5$ years

$\begin{array}{lrrrrrrrr}\text { Huvitus ... } & 83 & 84.3 & 7.3 & 8.4 & 58 & 10.3 & 38.0 & 51.7 \\ \text { Lavia....... } & 29 & 86.2 & 10.4 & 3.4 & 37 & 8.1 & 40.6 & 51.3 \\ \text { Syysjuovikas . } & 88 & 92.0 & 4.7 & 2.3 & 46 & 50.0 & 37.0 & 13.0 \\ \text { Charlottenthal } & 60 & 96.7 & 3.3 & 0 & 32 & 6.2 & 25.1 & 68.7 \\ \text { Wealthy ... } & 739 & 81.6 & 14.2 & 4.2 & 263 & 8.0 & 34.2 & 57.8 \\ \text { Antonovka .. } & 197 & 78.2 & 7.6 & 14.2 & 106 & 16.0 & 34.0 & 50.0\end{array}$


Taulukko 12. Wealthy-puiden talrehtiminen eri maalajeissa Spurilan bedelmätarhassa Paimiossa. Maalajitiedot koskevat jankkoa.

Table 12. The hibernation of Wealthy trees on different soils, Spurila fruit farm, Paimio. The soil data refer to the subsoil.

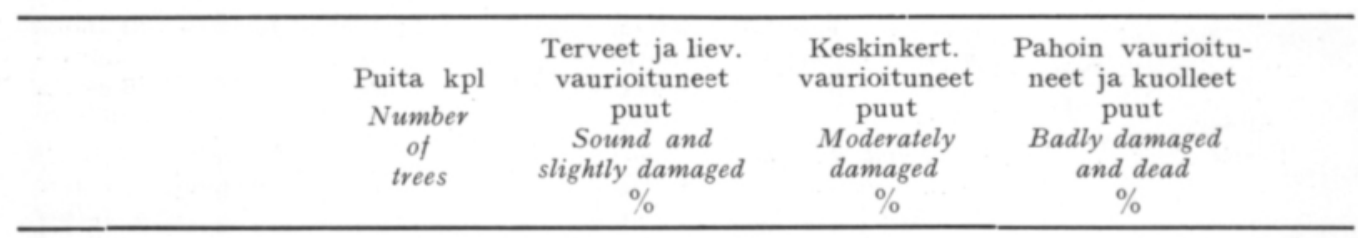

Lohko 1

Field $n: 0$ 1

Lohko 2

Field $n: 02$

Lohko 3

Field $n: 0 \quad 3$

Savimaa, maasto viettävää; puiden ikä $14-16 \mathrm{v}$.

Clay soil, sloping terrain; age of trees: 14-16 years

605

36.5

10.7

52.8

Hietamaa, maasto ylävää; puiden ikä $10 \mathrm{v}$.

Fine sand soil, elevated terrain; age of trees: 10 years 299

98.3

1.4

0.3

Savimaa, maasto viettävää; puiden ikä $8 \mathrm{v}$.

Clay soil, sloping terrain, age of trees: 8 years

322

85.4

7.8

6.8

tyisesti kuivan kesän jälkeen talvehtineet heikommin kasvaessaan nurmessa kuin mullosmaassa (4).

Muutamia tietoja on saatu myös nurmikompostilla pidetyistä hedelmätarhoista. Niiden mukaan puut eivät ole menestyneet tätä menetelmää käyttäen sen paremmin kuin tavallisessa nurmessa. Käytäessä tarkastamassa tällaisia hedelmätarhoja on useissa tapauksissa todettu nurmikomposti väärin hoidetuksi. Ruohoa ei ole alkukesällä riittävän usein leikattu ja kompostit ovat puiden alla olleet liian pieniä ja ruohottuneita, jollaisina ne eivät tehokkaasti estä kosteuden haihtumista.

\section{Kesällä 1955 saadun hedelmäsadon runsauden vaikutus omenapuun talvehtimiseen}

Useissa vastauksissa on ilmoitettu, että tuho on erityisesti kohdannut niitä puita, jotka kesällä 1955 antoivat runsaan sadon. Hedelmiä antamattomat ja heikkosatoiset puut ovat säilyneet paremmin. Vastaavanlaista on havaittu monien tuhotalvien jälkeen muuallakin $(4,8,12)$. Tämä ilmiö näyttää kuitenkin olevan riippuvainen myös puiden iästä sekä kasvuolosuhteista. Spurilan hedelmätarhassa Paimiossa (taulukko 12) ovat lohkossa 1, viettävässä savimaassa, kasvavista 14-16 vuotiaista Wealthy-puista tilan puutarhurin maininnan mukaan säilyneet terveinä tai vain lievin vaurioin pääasiallisesti ne, jotka v. 1955 antoivat satoa heikosti tai ei lainkaan. Lohkossa 2, ylävässä hietamaassa, kasvavat 10-vuotiaat saman lajikkeen puut talvehtivat hyvin siitä huolimatta, että ne antoivat runsaan sadon v. 1955. Tässä lohkossa kasvavien puiden sadoista on myös punnitustietoja. 
Taulukko 13. Omenapuiden talvehtiminen leikkaus- ja perusrunkokokeessa Puutarhantutkimuslaitoksella $1955-56$.

Table 13. The hibernation of apple-trees in the pruning and rootstock experiment in the Horticultural Department of the Agricultural Reseach Centre, 1955-1956.

\begin{tabular}{|c|c|c|c|c|c|}
\hline Lajike & Perusrunko & $\begin{array}{l}\text { Puita } \\
\text { kpl } \\
\text { Number }\end{array}$ & $\begin{array}{c}\text { Terveet ja liev. } \\
\text { vaurioituneet } \\
\text { kpl }\end{array}$ & $\begin{array}{c}\text { Keskinkertaisesti } \\
\text { vaurioituneet } \\
\text { kpl }\end{array}$ & $\begin{array}{l}\text { Pahoin vaurioitu- } \\
\text { neet ja kuolleet } \\
\text { kpl }\end{array}$ \\
\hline Variety & Rootstock & $\begin{array}{c}\text { of } \\
\text { trees }\end{array}$ & $\begin{array}{c}\text { Sound and } \\
\text { slightly damaged }\end{array}$ & $\begin{array}{c}\text { Moderately } \\
\text { damaged }\end{array}$ & $\begin{array}{l}\text { Badly damaged } \\
\text { and dead }\end{array}$ \\
\hline
\end{tabular}

\begin{tabular}{|c|c|c|c|c|}
\hline Melba & Normandie-siemenp. & 9 & 3 & 2 \\
\hline & seedlings & & & \\
\hline - & M IV & 9 & 1 & 3 \\
\hline , & M II & 7 & 3 & 1 \\
\hline Åkerö & Normandie-siemenp. & 9 & 3 & 2 \\
\hline & seedlings & & & \\
\hline " & M IV & 9 & 1 & 4 \\
\hline , & M II & 9 & 8 & - \\
\hline
\end{tabular}

Tulokset vain perusrungot huomioon ottaen:

The same results classified according to rootstock only:

\begin{tabular}{|c|c|c|c|c|}
\hline & kpl & $\%$ & $\%$ & $\%$ \\
\hline $\begin{array}{r}\text { Normandie-siemenp. } \\
\text { seedlings }\end{array}$ & 18 & $33.3 \pm 11.1$ & 22.2 & 44.5 \\
\hline M IV & 18 & $11.1 \pm 7.4$ & 38.9 & 50.0 \\
\hline M II & 16 & $68.7+11.1$ & 6.2 & 25.1 \\
\hline
\end{tabular}

Lohkossa 3, joka on viettävää savimaata, tuottivat 8-vuotiaat Wealthy-puut niin ikään runsaasti hedelmiä ja selviytyivät kuitenkin verraten vähäisin vaurioin.

Todennäköisesti juuri runsaan sadon heikontamina ovat kestäviksi ja samalla runsassatoisiksi tunnetut Snygg- ja Harlamovski-lajikkeet monin paikoin talvehtineet huonosti. Talvenkestävyyden riippuvaisuuden talvea edeltäneen kasvukauden sadosta on havaittu toisinaan olevan jopa niin huomattava, että kestävät lajikkeet saattavat runsaan sadon annettuaan talvehtia heikommin kuin arat lajikkeet, jotka eivät ole tuottaneet satoa (5).

\section{Perusrungon merkitys omenapuun talvehtimisessa}

Perusrunkoja koskevat tiedot jäivät verraten niukoiksi. Valtaosa vastaajista ilmoitti, ettei heillä ole tiedossa millä perusrungolla puut kasvavat. Niissä hedelmätarhoissa, joista perusrungot oli mainittu, yhden lajikkeen puut tavallisesti kasvoivat yhdellä ja toisen lajikkeen puut toisella perusrunkotyypillä, joten vertailu ei ole mahdollista.

Yleisesti on voitu kuitenkin todeta, ettei perusrungon vaikutus ole ollut määräävä omenapuiden talvehtimisessa $1955-56$. Monissa tapauksissa puiden ei ole 
Taulukko 14. Alle 5-vuotiaiden omenapuiden talvehtiminen eri perusrungoilla Pikkolan hedelmätarhassa Kangasalla. Maalaji hiekka, hieta ja hiesu. Maasto viettävä.

Table 14. The hibernation of apple-trees less than 5 years old on various rootstocks, Pikkola fruit farm, Kangasala (near Tampere). Soil type: coarse sand, fine sand and silt. Sloping terrain.

\begin{tabular}{|c|c|c|c|c|c|}
\hline $\begin{array}{l}\text { Lajike } \\
\text { Variety }\end{array}$ & $\begin{array}{c}\text { Perusrunko } \\
\text { Rootstock }\end{array}$ & $\begin{array}{l}\text { Puita } \\
\text { kpl } \\
\text { Number } \\
\text { of trees }\end{array}$ & $\begin{array}{c}\text { Terveet ja liev. } \\
\text { vaurioituneet } \\
\text { Sound and } \\
\text { slightly damaged } \\
\%\end{array}$ & $\begin{array}{c}\text { Keskinkertaisesti } \\
\text { vaurioituneet } \\
\text { Moderately } \\
\text { damaged } \\
\% \\
\end{array}$ & $\begin{array}{c}\text { Pahoin vaurioitu- } \\
\text { neet ja kuolleet } \\
\text { Badly damaged } \\
\text { and dead } \\
\%\end{array}$ \\
\hline Lobo & $\begin{array}{l}\text { Antonovka-siemenp. } \\
\text { seedling }\end{array}$ & 391 & $69.3 \pm 2.3$ & 11.0 & 19.7 \\
\hline , & $\begin{array}{c}\text { Normandie-siemenp. } \\
\text { seedling }\end{array}$ & 173 & $64.2 \pm 3.6$ & 20.8 & 15.0 \\
\hline Wealthy & $\begin{array}{l}\text { Antonovka-siemenp. } \\
\text { seedling }\end{array}$ & 207 & $58.9 \pm 3.4$ & 20.8 & 20.3 \\
\hline , & $\begin{array}{r}\text { Normandie-siemenp. } \\
\text { seedling }\end{array}$ & 88 & $50.0 \pm 5.3$ & 15.9 & 34.1 \\
\hline Åkerö & $\begin{array}{l}\text { Antonovka-siemenp. } \\
\text { seedling }\end{array}$ & 293 & $84.6 \pm 2.1$ & 6.8 & 8.6 \\
\hline , & M II & 62 & $87.1 \pm 4.3$ & 4.8 & 8.1 \\
\hline
\end{tabular}

havaittu menestyneen sen paremmin kestävinä kuin arkoina pidetyillä perusrungoilla. Tähän seikkaan lienevät syynä etupäässä syksyn 1955 poikkeukselliset sääsuhteet (taulukot 1 ja 2). Syys- ja lokakuu olivat huomattavasti normaalia lämpimämpiä ja sateisempia. Tästä oli seurauksena, että puiden kasvu jatkui hyvin myöhään. Kun lämpötila marraskuun lopulla äkillisesti aleni, jolloin paikoitellen Etelä-Suomessakin mitattiin yli $20^{\circ}$ :n pakkasia, puut olivat yleisesti vielä lehdessä. Tästä johtunee, ettei perusrungolla todettu olleen samanlaista vaikutusta puun tuleentumiseen kuin sääoloiltaan normaaleina syksyinä. Sen, että perusrungoilla sittenkin on huomattava merkitys hedelmäpuiden talvenkestävyydelle, ovat lukuisat eri tahoilla suoritetut kokeet kyllä kiistattomasti osoittaneet $(1,3,6,8$, $9,10,11,12,14)$.

Puutarhantutkimuslaitoksella v. 1952 aloitetussa omenapuiden leikkaus- ja perusrunkokokeessa ilmeni talven 1955-56 jälkeen hyvin selviä eroja eri perusrungoilla kasvavien Melba- ja Åkerö-puiden talvehtimisessa (taulukko 13). Tällöin M II-puiden todettiin kestäneen selvästi paremmin kuin Normandie- ja M IVperusrunkoihin varrennettujen puiden. Myös Kanadassa mainitaan M II-puiden kestäneen talvia verraten hyvin (1). Tämän perusrungon roudankestävyys on kuitenkin todettu heikoksi $(7,9,11)$.

Pikkolan hedelmätarhassa Kangasalla ovat Lobo- ja Wealthy-puut selviytyneet jonkin verran paremmin Antonovka- kuin Normandie-siemenperusrungoilla (taulukko 14). Ero ei kuitenkaan ole ollut merkitsevä. Tässäkin hedelmätarhassa ovat M II-perusrungoilla kasvavat Åkerö-puut menestyneet hyvin.

Edellä mainitussa omenapuiden leikkaus- ja perusrunkokokeessa ei erilaisten leikkausten todettu vaikuttaneen puiden talvehtimiseen. Myös kokonaan leikkaa- 
Kuva 4. Åkerö-puu, joka on kärsinyt pahoja silmuvaurioita. Useimmilla lajikkeilla vauriot ilmenivät 1955-56 etupäässä lehtisilmujen tuhoutumisena. Tämä ilmiö johtuu yleensä myöhäissyksyn pakkasista ja esiintyy erityisesti silloin, kun puiden tuleentuminen on myöhässã.

Fig. 4. An Akerö tree with severely damaged buds. In most varieties the damage during the winter 1955-1956 mainly appeared as a destruction of the buds. This phenomenon is usually caused by frost in the late autumn; it occurs particularly when the ripening of the trees has been delayed.

matta jätetyissä puissa esiintyi yhtä paljon vaurioita kuin runsaasti leikatuissa puissa.

Kestävien välirunkojen käytön merkityksestä

Omenapuulajikkeiden talvehtimisesta varrennettuna kestäviin välirunkoihin käsittää tiedusteluaineisto vain muutaman maininnan. Puutarhantutkimuslaitoksella ilmeni tämän menetelmän edullinen vaikutus selvästi arimpien lajikkeiden talvehtimisessa. Kokeessa, jossa välirunkoina olivat $\mathrm{mm}$. Kaneli, Sokeri Miron ja Lepaan meloni, sel-

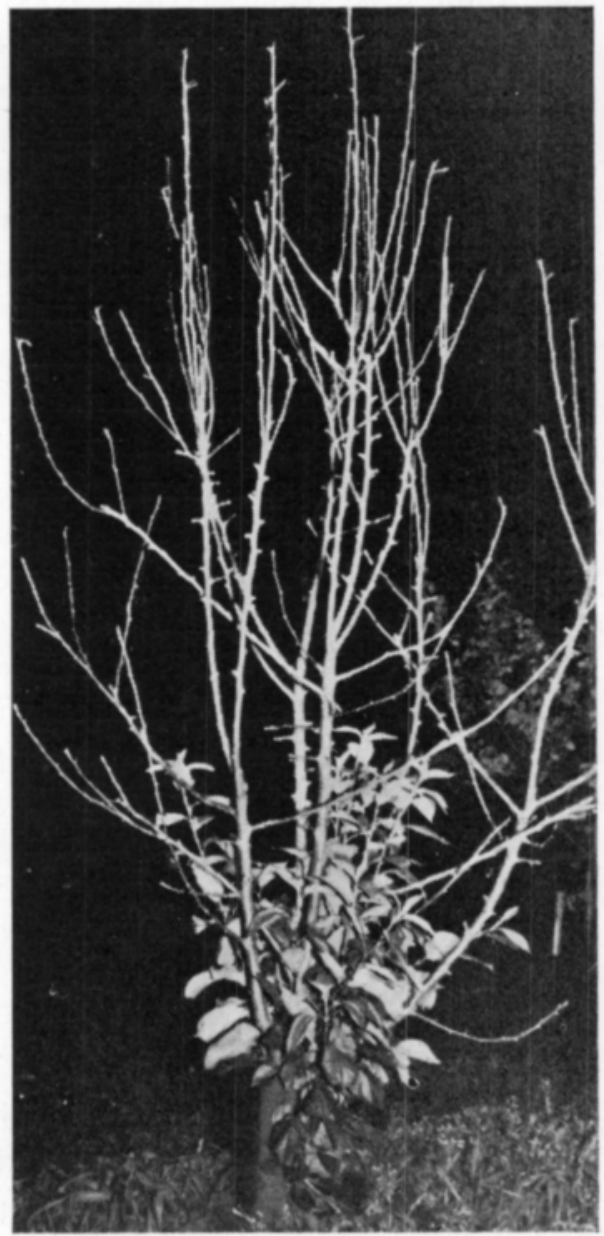
viytyivät Melba, Wealthy, Linda ja Patricia hyvin. Viereisissä puuriveissä omalla rungollaan kasvaessaan mainitut lajikkeet kärsivät sitä vastoin pahoja vaurioita. Kasvupaikkana oli alava hiekkamaa.

\section{Tuhojen syistä}

Tarkasteltaessa syitä talven $1955-56$ aikana hedelmänviljelyksillä tapahtuneisiin tuhoihin huomio kiintyy lähinnä seuraaviin tekijöihin:

- Kesällä 1955 vallinnut ankara kuivuus

— Normaalia lämpimämpi ja sateisempi syys- ja lokakuu

- Lämpötilan äkillinen aleneminen marraskuun lopulla

— Poikkeuksellisen kylmä talvi joulukuun alusta lähtien

Kesän loppupuolella vallitsevan pitkäaikaisen kuivuuden on todettu voivan koitua hedelmäpuiden talvehtimisen kannalta vaaralliseksi (4). Kova kuivuus 
nimittäin keskeyttää kasvun. Syksyllä sääolojen muututtua kasvu alkaa uudelleen ja jatkuu yleensä sitä myöhäisempään, mitä lämpimämpi ja kosteampi syksy on. Mikäli tällöin lämpötilassa tapahtuu äkillistä huomattavaa laskua, seurauksena on puiden vaurioituminen. Tällaista ilmeni $\mathrm{mm}$. 1950-51 (13).

Elokuussa 1955 hedelmäpuut olivat pitkän poutakauden rasittamina yleisesti nääntyneitä. Niiden lehdet alkoivat riippua velttoina, ja niissä ilmeni voimakasta ravinteiden puutetta. Syyskuun sateiden alettua palautui lehtien nestejännitys, ja niiden väri alkoi muuttua tummemmaksi. Vasta tässä vaiheessa puut saattoivat käyttää hyväkseen keväällä maahan annettuja lannoitteita. Syys- ja lokakuun ollessa tavallista runsassateisemmat ja lämpimämmät puut elpyivät voimakkaaseen ja myöhään jatkuvaan kasvuun. Lämpötilan nopeasti alentuessa marraskuun lopulla ja pitkän pakkaskauden alkaessa joulukuussa puiden versot olivat varsinkin alavilla kasvupaikoilla monilla lajikkeilla vielä tuleentumattomia. Yleisesti voitiinkin todeta, että pakkasen vioittamat lehdet jäivät puihin pitkäksi aikaa. Mainituilla alkutalven pakkasilla on todennäköisesti ollut merkittävin osuus talven 1955 - 56 tuhoissa. Tätä osoittanee se, että vauriot useilla lajikkeilla ilmenivät enimmäkseen lehtisilmujen tuhoutumisena ja versojen puuosan mustumisena. Nämä ilmiöt johtuvat yleensä alkutalven pakkasista ja esiintyvät erityisesti silloin, kun puiden tuleentuminen on myöhässä ( 8 ; kuva 4). Vaille merkitystä eivät liene jääneet myöskään helmikuun viikkokausia kestäneet ankarat pakkaset.

Kirjoittaja esittää lämpimät kiitoksensa kaikille niille, jotka lähettivät tietoja hedelmäpuiden talvehtimisesta. Erityisesti kiitän prof. Olavi Meurmania hänen työlleni antamastaan tuesta sekä puutarhaopettaja ANNI TENKKUa, joka arvokkaalla tavalla auttoi aineistoa käsiteltäessä. Hedelmänviljelijäin yhdistystä kiitän hyvästä yhteistyöstä. 


\title{
KIRJALLISUUS
}

(1) Blair, D. S. \& Cannon, H. B. \& Beingessner, H. F. 1955. Fruit pomology. Apple rootstocks. Div. of Hort. Centr. Exp. Farm, Ottava 1949-53.

(2) Collan, O. 1934. Suomen hedelmänviljelys hedelmätarhojamme v. 1929 kohdanneen tuhon valossa. Valt. maatal. koetoim. julk. 60: 1-68.

(3) Davis, M. B. \& Blair, D. S. \& Cannon, H. B. 1955. Pomology. Winter injury. Div. of Hort. Centr. Exp. Farm, Ottava 1934-1948, p. 5-14.

(4) Gardner, V. R. \& Bradford, F. C. \& Hooker, H. D. 1939. The fundamentals of fruit production, p. $284-377$. New York.

(5) Gourley, J. H. \& Howlett, F. S. 1947. Modern fruit production, p. 396-420. New York.

(6) HILKEnвäumer, F. 1942. Einfluss von Unterlage und Standort auf den Frostschaden am Kernobst im Winter 1939-40 in Baumschule. Kühn. Arch. 56: 1-24.

(7) Keмmer, E. 1943. Uber die Regenerationsfähigkeit der Obstgehölzwurzeln. Gartenbauwiss. 18: $101-117$.

(8) Kemmer, E. \& Schulz, F. 1955. Das Frostproblem im Obstbau, p. 31-82. München.

(9) LoEweL, E. L. 1942. Beobachtungen über Frostschäden des Winters 1941/1942. Ref. Gartenbauwiss. 17: $80-81$.

(10) Loewel, \& Schubert, W. 1941. Der Einfluss der Unterlage auf die Frostwiderstandfähigkeit verschiedener Apfel und Pflaumen sorten. Gartenbauwiss. 15: 453 - 462.

(11) Meurman, O. 1943. Omenapuiden ilmastollisesta kestävyydestä. Puutarhavilj. liit. julk. 27 : 1-8.

(12) Rudorf, W. \& Sснміdт, M. \& Rомвасн, R. 1942. Ergebnisse einer Erhebung über die im Winter 1939/40 an Obstgehölzen im Deutschen Reich aufgetretenen Frostschäden. Gartenbauwiss. 16: $550-788$.

(13) Sйкö, J. 1951. Havaintoja hedelmäpuiden talvehtimisesta $1950-51$. Koetoim. ja käyt. 1951, $6-7: 1$.

(14) Tukey, H. B. \& Brase, K. D. 1935. Random notes on fruit tree rootstocks and plant propagation II. N. Y. St. Agric. Exp. Sta. Bull. 657: 1-26.

\section{S U M M A R Y :}

\author{
ON THE DAMAGE TO FRUIT FARMING IN FINLAND, 1955-56
}

ЈААKКо SÄкӧ

Horticultural Department of Agricultural Research Centre, Piikkiö

The dry summer and the subsequent severe winter have again caused considerable damage to fruit farming in our country. In order to obtain an idea of the extent and type of damage in the various parts of the country, a questionnaire was distributed, jointly with the Fruit Farmers' Association, to 717 fruit farmers. In the questionnaires, of which 171 were returned with sufficiently complete information, answers were requested as to the number of trees of various species which had passed the winter without any injury whatsoever, as well as of the damaged and dead trees. Information was further requested relating to soil, character of the terrain, treatment of the soil on the fruit farm, etc.

The material thus obtained for scrutiny consisted of 45.000 apple-trees. Certain data on pear, plum, and cherry-trees were also obtained. The answers were grouped so as to constitute 10 more or less natural hibernation regions which can be seen from the accompanying map.

The hibernation of apple-trees in the different regions has been detailed in tables $3,4,5,6,7$ and 8 . Tables 9, 10, 11 and 12 show how apple-trees have stood the winter under different conditions 
of character of terrain and soil quality, and on grass land or upon bare soil. The data on the stocks have been compiled in tables 13 and 14 .

The study of the present material reveals that the varieties Kaneli and Sokeri-Miron have to be considered the most hardy ones among the varieties which are more commonly cultivated in our country. On the other hand, Oranie, Signe Tillisch, Linda and Wealthy would be most easily damaged among our standard varieties. The influence of the stocks has not had any decisive significance in regard to the hibernation of the trees this time. However, it was found, e.g., at the Research Institute at Piikkiö that Akerö and Melba trees have borne up better in the stock test on M II than, for instance, on M IV and Normandie stocks. The character of the soil and its conditions of slope, again, have had a very marked influence upon the extent of damage. 